\title{
Improving cell distribution on 3D additive manufactured scaffolds through engineered seeding media density and viscosity
}

Citation for published version (APA):

Cámara-Torres, M., Sinha, R., Mota, C., \& Moroni, L. (2020). Improving cell distribution on 3D additive manufactured scaffolds through engineered seeding media density and viscosity. Acta Biomaterialia, 101, 183-195. https://doi.org/10.1016/j.actbio.2019.11.020

Document status and date:

Published: 01/01/2020

DOI:

10.1016/j.actbio.2019.11.020

Document Version:

Publisher's PDF, also known as Version of record

Document license:

Taverne

Please check the document version of this publication:

- A submitted manuscript is the version of the article upon submission and before peer-review. There can be important differences between the submitted version and the official published version of record.

People interested in the research are advised to contact the author for the final version of the publication, or visit the DOI to the publisher's website.

- The final author version and the galley proof are versions of the publication after peer review.

- The final published version features the final layout of the paper including the volume, issue and page numbers.

Link to publication

\footnotetext{
General rights rights.

- You may freely distribute the URL identifying the publication in the public portal. please follow below link for the End User Agreement:

www.umlib.nl/taverne-license

Take down policy

If you believe that this document breaches copyright please contact us at:

repository@maastrichtuniversity.nl

providing details and we will investigate your claim.
}

Copyright and moral rights for the publications made accessible in the public portal are retained by the authors and/or other copyright owners and it is a condition of accessing publications that users recognise and abide by the legal requirements associated with these

- Users may download and print one copy of any publication from the public portal for the purpose of private study or research.

- You may not further distribute the material or use it for any profit-making activity or commercial gain

If the publication is distributed under the terms of Article 25fa of the Dutch Copyright Act, indicated by the "Taverne" license above, 
Full length article

\title{
Improving cell distribution on 3D additive manufactured scaffolds through engineered seeding media density and viscosity
}

\author{
Maria Cámara-Torres, Ravi Sinha, Carlos Mota, Lorenzo Moroni* \\ Complex Tissue Regeneration Department, Maastricht University, MERLN Institute for Technology-Inspired Regenerative Medicine, Universiteitssingel 40, \\ 6229 ER Maastricht, The Netherlands
}

\section{A R T I C L E I N F O}

\section{Article history:}

Received 31 July 2019

Revised 21 October 2019

Accepted 8 November 2019

Available online 13 November 2019

\section{Keywords:}

Additive manufacturing

3D scaffolds

Macromolecules

Static seeding

Stem cells

Bone tissue engineering

\begin{abstract}
A B S T R A C T
In order to ensure the long-term in vitro and in vivo functionality of cell-seeded 3D scaffolds, an effective and reliable method to control cell seeding efficiency and distribution is crucial. Static seeding on 3D additive manufactured scaffolds made of synthetic polymers still remains challenging, as it often results in poor cell attachment, high cell sedimentation and non-uniform cell distribution, due to gravity and to the intrinsic macroporosity and surface chemical properties of the scaffolds. In this study, the biocompatible macromolecules dextran and Ficoll (Ficoll-Paque) were used for the first time as temporary supplements to alter the viscosity and density of the seeding media, respectively, and improve the static seeding output. The addition of these macromolecules drastically reduced the cell sedimentation velocities, allowing for homogeneous cell attachment to the scaffold filaments. Both dextran and Ficoll-Paque -based seeding methods supported human mesenchymal stromal cells viability and osteogenic differentiation post-seeding. Interestingly, the improved cell distribution led to increased matrix production and mineralization compared to scaffolds seeded by conventional static method. These results suggest a simple and universal method for an efficient seeding of 3D additive manufactured scaffolds, independent of their material and geometrical properties, and applicable for bone and various other tissue regeneration.
\end{abstract}

\section{Statement of significance}

Additive manufacturing has emerged as one of the desired technologies to fabricate complex and patientspecific 3D scaffolds for bone regeneration. Along with the technology, new synthetic polymeric materials have been developed to meet processability requirements, as well as the mechanical properties and biocompatibility necessary for the application. Yet, there is still lack of methodology for a universal cell seeding method applicable to all additive manufactured 3D scaffolds regardless of their characteristics. We believe that our simple and reliable method, which is based on adjusting the cell settling velocity to aid cell attachment, could potentially help to maximize the efficiency, and therefore, functionality of cell-seeded constructs. This is of great importance when aiming for both in vitro and future clinical applications.

(c) 2019 Acta Materialia Inc. Published by Elsevier Ltd. All rights reserved.

\section{Introduction}

In vivo, cells are surrounded by a complex 3D microenvironment that supports their growth and assembly into functional tissues. Upon tissue damage caused by trauma or disease, the structural integrity of this extracellular matrix (ECM) can be compromised leading to lack of essential cues for functional tissue performance, and the requirement of suitable replacements. By

\footnotetext{
* Corresponding author.

E-mail address: 1.moroni@maastrichtuniversity.nl (L. Moroni).
}

using scaffolds, tissue engineering and regenerative medicine (TERM) aim to provide artificial ECM-like structures, which try to mimic the native tissue in terms of architecture, chemistry or mechanical properties to guide cells into the first steps of the regeneration process $[1,2]$. To allow cell infiltration, tissue ingrowth and vascularization, 3D scaffolds with a highly interconnected porous structure are required [3,4]. In the past decade, additive manufacturing (AM) and, more specifically, melt extrusion-based techniques, have emerged as one of the most appealing technologies to produce scaffolds for TERM $[5,6]$. Compared to other conventional methods such as gas foaming/particulate leaching 
[7,8], freeze-drying $[9,10]$ or phase separation [11,12], AM allows the reproducible fabrication of complex 3D structures with interconnected, high porosity, from various types of biocompatible and biodegradable polymers with optimum mechanical properties desired for tissue regeneration applications.

Efficient cell seeding of 3D scaffolds is a key step towards the development of in vitro tissues for TERM applications. Cell density and their spatial distribution in macroporous scaffolds are critical to ensure the functionality of the engineered tissue, as these parameters will dictate intercellular and cell-material interactions, thereby affecting different cellular behaviors such as migration, proliferation, differentiation and matrix production $[13,14]$. To improve cell distribution within 3D scaffolds, different dynamic seeding methods have been applied. Compared to static seeding, dynamic seeding methods, which apply an external force to facilitate cell penetration, such as flow perfusion, centrifugation, orbital shaking, and spinner flask, have shown to result in better cell distribution on scaffolds fabricated with conventional techniques [15-19]. Moreover, culture of these 3D scaffolds in perfusion bioreactors after static seeding has also demonstrated to enhance cell distribution and tissue formation [20]. However the use of bioreactors require specific lab equipment and expertise, and perfusion flow right after seeding results in significant decrease in cell number in AM 3D scaffolds [21]. Overall, due to the intrinsic scaffold characteristics, i.e. large and interconnected pore architectures, most of the dynamic techniques show limited applicability for seeding or culture AM scaffolds. Furthermore, the lack of specific cell adhesion sites in the majority of the polymers suitable for AM leads to poor cell-material interactions, which along with the gravitational force results in cell sedimentation during static seeding and, therefore, non-uniform cell distribution within the scaffold. Nevertheless, the simplicity of the static seeding over dynamic seeding has led to further developments of this method for seeding AM 3D scaffolds, starting by the modification of basic seeding parameters such as cell number, seeding volume, seeding time and seeding vessel optimization. For instance, seeding times up to $4 \mathrm{~h}$, seeding volumes comparable to the scaffold's free volume and not very large cell numbers have shown to give the highest cell seeding efficiency upon static seeding [22-24]. On the other hand, different surface modification techniques capable of improving the chemical and biological performance of synthetic polymers have also shown to increase cell adhesion in AM 3D scaffolds. For example, plasma modification using oxygen [25] or nitrogen [26,27] have shown to increase cell adhesion of osteoblastic cell lines in $\operatorname{poly}(\varepsilon$-caprolactone) (PCL) scaffolds. Chondrocytes adhesion on poly(ethylene oxide terephthalate)/poly(butylene terephthalate) (PEOT/PBT) AM 3D scaffolds has also been improved by the addition of carboxylic groups to the polymer surface via acrylic acid plasma polymerization [28]. Surface functionalization using adhesive polymers such as poly(dopamine) have also demonstrated to improve adhesion of different cell types on PCL and poly(lactic acid) (PLA) scaffolds [29-31]. As an alternative to chemical modification of polymer surfaces, better cell attachment along the scaffold cross section has been attained by decreasing the flow rate of the seeding media through the scaffold's pores $[32,33]$. By varying the strand distance or the angle of deposition in each layer, AM 3D scaffolds with pore size gradients along the vertical direction [32] or with different lay-down patterns [33] were fabricated and resulted in enhanced cell attachment and distribution. This was, however, in exchange of varying the scaffolds mechanical properties and, more importantly, reducing the pore size, which hinders cell migration, nutrients and oxygen availability, waste management, and angiogenesis for pore sizes smaller than $300 \mu \mathrm{m}[4,34-36]$.

A large improvement in cell seeding efficiency and distribution was recently obtained by seeding AM 3D scaffolds with cell-laden hydrogels, which showed to retain almost the complete cell number mixed within the hydrogel precursor [37-41]. However, these hybrid systems are multi-step and require fast gelation times. In addition, cells are exposed to two different microenvironments: the hard scaffold filaments and the soft hydrogel carrier. As it is widely accepted that substrate stiffness can direct cell fate [42], having these types of dual systems might mask the effect of the scaffold material and lead to unexpected results.

Although previous strategies have shown some improvement on cell seeding efficiency and distribution, they require modification of the scaffold's surface chemistry or architecture, influencing the overall microenvironment. Therefore, there is still lack of methodology and knowledge of an elegant cell seeding method applicable to all AM 3D scaffolds regardless of their characteristics. Here, we introduce a novel seeding technique based on controlling cell settling velocity upon static seeding that can be applied to all types of AM3D scaffolds without requiring any chemical or architectural modification. Two biocompatible macromolecules (macroMs) were employed for the first time as supplements to independently tune (i) the viscosity or (ii) the density of the cell seeding media. Cells seeded with this novel technique were morphologically characterized using immunofluorescence and scanning electron microscopy. Furthermore, the osteogenic differentiation of human mesenchymal stromal cells (hMSCs) seeded with the macroM-based solutions on AM 3D scaffolds was investigated using various biochemical and molecular assays to evaluate the effect of macroMs on a specific cell differentiation.

\section{Materials and methods}

\subsection{Scaffolds fabrication}

Scaffolds were fabricated via a melt-extrusion based AM technique (Bioscaffolder 3.1, SysENG, Germany). The copolymer poly(ethylene oxide terephthalate)/poly(butylene terephthalate) (PEOT/PBT), with a PEO molecular weight of 300 Da and PEOT/PBT blocks ratio 55/45 wt\% (300PEOT55PBT45, PolyVation, The Netherlands) was used. Briefly, the cartridge was filled with PEOT/PBT pellets, heated at $195^{\circ} \mathrm{C}$ and extruded by applying a pressure of 4 bar, an auger screw rotation of $40 \mathrm{rpm}$ and a translation speed of $10 \mathrm{~mm} \mathrm{~s}^{-1}$. The scaffold architecture consisted of a 0-90 pattern, with a $250 \mu \mathrm{m}$ fiber diameter, $200 \mu \mathrm{m}$ layer thickness and $750 \mu \mathrm{m}$ strand distance (center to center), giving an expected $\mathrm{x}-\mathrm{y}$ porosity of approximately $500 \mu \mathrm{m}$. Cylindrical scaffolds of $4 \mathrm{~mm}$ diameter and $4 \mathrm{~mm}$ height were punched out from a $20 \times 20 \times 4 \mathrm{~mm}$ manufactured block using a biopsy punch and used for further experiments.

\subsection{Density and viscosity measurements of Dextran and Ficoll based solutions}

Ficoll-Paque $^{\mathrm{TM}}$ Plus solution (GE Healthcare) (Ficoll-Pq) was diluted to 80, 60, 40 and 20 vol\% with cell culture medium (CM), consisting of $\alpha$ MEM with Glutamax and no nucleosides (Gibco) supplemented with $10 \mathrm{vol} \%$ FBS (Sigma-Aldrich), penicillin (100 $\mathrm{U} / \mathrm{ml}$ ) and streptomycin $(100 \mu \mathrm{g} / \mathrm{ml})$ (Fisher-Scientific). Similarly, 10,5 , and 2.5 wt\% dextran (500 kDa, Pharmacosmos) solutions were prepared in $\mathrm{CM}$. Densities were calculated by weighing known volumes of each of the solutions (accuracy $\pm 0.1 \mathrm{ml}$ ) in a high precision balance (accuracy $\pm 0.1 \mathrm{mg}$ ) and applying the density formula. The relative viscosity (with respect to water) of the solutions was empirically determined by timing the flow of water and the same volume of each solution through the same fluidic circuit at the same constant pressure. 


\subsection{Determination of hMSCs density using density gradient separation}

Density of hMSCs was measured using Ficoll-Pq density gradient centrifugation. The Ficoll-Pq solution was diluted to 80 , 60,40 and 20 vol\% with appropriate volumes of CM containing phenol red, which helped to visualize the layers of the gradient. Starting from 100 vol\% Ficoll-Pq solution, $2 \mathrm{ml}$ of each solution were carefully layered on top of each other in decreasing order in a $15 \mathrm{ml}$ conical tube. One million cells in $\mathrm{CM}$ were layered on top of the $20 \%$ Ficoll-Pq layer. The tube was then centrifuged at $500 \mathrm{rcf}$ for $20 \mathrm{~min}$ at room temperature (RT). Subsequently, the layers were carefully separated by pipetting and the cells in each layer were imaged via brightfield microscopy and quantified using a Neubauer chamber. As a comparative method, cell density was additionally determined through buoyancy force-driven separation, which does not require the application of mechanical forces. For the buoyancy separation, the various concentrations of Ficoll-Pq media were similarly layered in a $15 \mathrm{ml}$ conical tube starting from 100 vol\% Ficoll-Pq solution. Here, 1 million cells in medium were carefully pipetted at the bottom of the tube under the 100\% FicollPq layer using a long syringe needle, without disturbing the layers. The tube was then incubated at RT for $3 \mathrm{~h}$ to let cells be pushed by buoyancy forces to layers of similar density. After separation, the layers were collected separately and cells present in each solution were imaged and quantified using a Neubauer chamber.

\subsection{Cell seeding and culture}

\subsubsection{Cell expansion}

HMSCs isolated from bone marrow were purchased from Texas A\&M Health Science Center, College of Medicine, Institute for Regenerative Medicine (Donor d8011L, female, age 22). Cryopreserved vials at passage 3 were plated at a density of 1,000 cells $\mathrm{cm}^{-2}$ in tissue culture flasks and expanded until approximately $80 \%$ confluency in $\mathrm{CM}$ without Pen/Strep at $37^{\circ} \mathrm{C} / 5 \% \mathrm{CO}_{2}$.

\subsubsection{Cell seeding and culture in $3 D$ scaffolds}

Scaffolds were disinfected in $70 \%$ ethanol for $20 \mathrm{~min}$, washed 3 times with phosphate buffered saline (PBS) and incubated overnight in $\mathrm{CM}$ for protein attachment. Before seeding, scaffolds were dried on top of a sterile filter paper and placed in the wells of a non-treated hydrophobic tissue culture well plate. Trypsinized passage 4 hMSCs suspension was centrifuged for $5 \mathrm{~min}$ at $500 \mathrm{rcf}$ and the cells were then resuspended in $\mathrm{CM}$, dextran-based $\mathrm{CM}$, or Ficoll-Fq -based CM at a density of 200,000 cells per $37 \mu l$ (approximate scaffold free volume). Dextran-based CM consisted of $10 \mathrm{wt} \%$ dextran in $\mathrm{CM}$ and Ficoll-Pq based CM consisted of 60 vol\% Ficoll-Pq in a FBS adjusted cell culture medium ( $\alpha$-MEM supplemented with 25 vol\% FBS and 1 vol\% Penstrep, to obtain $10 \mathrm{vol} \% \mathrm{FBS}$ in the final medium). A $37 \mu$ droplet of each cell suspension each was placed on top of each scaffold, drawn into the scaffold's free volume by capillary forces and held inside the pores by the hydrophobic well under it. Seeded scaffolds were incubated for $4 \mathrm{~h}$ at $37^{\circ} \mathrm{C} / 5 \% \mathrm{CO}_{2}$ to allow cell attachment. After this time, scaffolds were transferred to new wells containing $1.5 \mathrm{ml}$ of basic media (BM) (CM supplemented with $200 \mu \mathrm{M} \mathrm{L-}$ Ascorbic acid 2-phosphate (Sigma-Aldrich)). BM was replaced after $24 \mathrm{~h}$ and every two or three days from then on. To evaluate hMSCs osteogenic differentiation, scaffolds were cultured for another 21 days in BM or mineralization media (MM) after 7 days in BM. MM consisted of BM supplemented with $10 \mathrm{nM}$ dexamethasone (Sigma-Aldrich) and $10 \mathrm{mM} \beta$-glycerophosphate (Sigma-Aldrich).

To visualize the potential entrapment of macromolecules within the scaffold after seeding, cells were resuspended in 10 wt\% dextran-FITC (Fluorescein Isothiocyanate-Dextran 500 kDA,
Sigma-Aldrich) or 60 vol\% Ficoll-Pq-FITC at the same cell density $(200,000$ cells in $37 \mu \mathrm{l})$. The Ficoll-Pq-FITC based CM was prepared by first dissolving 5.7\% (wt/vol) polysucrose-FITC (400 kDa, Sigma-Aldrich) and 9\% (wt/vol) sodium diatrizoate hydrate (SigmaAldrich) in sterile water, to match Ficoll-Pq composition. $60 \mathrm{vol} \%$ of this solution was prepared in FBS adjusted cell CM as previously described. A $37 \mu \mathrm{l}$ droplet of each cell suspension was placed on top of each scaffold and incubated for $4 \mathrm{~h}$ at $37^{\circ} \mathrm{C} / 5 \% \mathrm{CO}_{2}$ to allow cells attachment. After this time, scaffolds were transferred to new wells containing $1.5 \mathrm{ml}$ of BM and cultured for $24 \mathrm{~h}$.

To rule out macromolecular adhesion, as well as macroMdriven enhancement of serum proteins adsorption to the scaffold filaments, as the causes of improved cell seeding, scaffolds were pre-incubated for $4 \mathrm{~h}$ with dextran and Ficoll-Pq -based CM. Nonadsorbed macromolecules were removed by a single scaffold wash with PBS and the scaffolds were then dried on top of a sterile filter paper. Subsequently, scaffolds were seeded with $37 \mu \mathrm{l}$ of $\mathrm{CM}$ containing 200,000 cells and incubated for $4 \mathrm{~h}$ at $37^{\circ} \mathrm{C} / 5 \% \mathrm{CO}_{2}$ to allow cell attachment, after which scaffolds were analyzed.

\subsubsection{Cell seeding in $2 D$ for viability and osteogenic differentiation evaluation}

Trypsinized passage 4 hMSCs were centrifuged and resuspended in $\mathrm{CM}$, dextran-based $\mathrm{CM}$ or Ficoll-Pq -based $\mathrm{CM}$ at a density of 200,000 cells per $37 \mu$ l. Cell suspensions were incubated at $37^{\circ} \mathrm{C} / 5 \% \mathrm{CO}_{2}$ in plates mimicking the $4 \mathrm{~h}$ seeding in 3D scaffolds in contact with the macroMs. To assess the viability of cells when in a macroMs solution, incubation was done in presence of NucBlue ${ }^{\circledR}$ Live and NucGreen ${ }^{\circledR}$ Dead reagents (ReadyProbes ${ }^{\circledR}$ Cell Viability Imaging Kit, Invitrogen) as defined by the manufacturer protocol and imaged at $\mathrm{t}=0 \mathrm{~h}$ and $\mathrm{t}=4 \mathrm{~h}$ after seeding using an inverted fluorescent microscope (Eclipse, Ti2-e, NIKON). For optimal visualization in the reported images, live cells were false colored in green while dead cells were given a red color. After $4 \mathrm{~h}$, the remaining cell suspensions (without cell viability reagents) were centrifuged, the macroMs containing media was removed and cells were resuspended in fresh CM to mimic the post-seeding culture condition of cells in scaffolds. Cells were counted and seeded at density of 5,000 cells $\mathrm{cm}^{-2}$ in tissue culture polystyrene well plates. Media was refreshed every two or three days. To evaluate hMSCs osteogenic differentiation, scaffolds were cultured for 21 days in BM or MM after 7 days in BM.

\subsection{Imaging and quantification of cell distribution within scaffold cross section}

After seeding and $4 \mathrm{~h}$ incubation for attachment, scaffolds were washed with PBS and fixed with 4 wt\% paraformaldehyde for 30 min, followed by washing steps with PBS. Cells were permeabilized using 0.1 vol\% Triton-X for $30 \mathrm{~min}$, washed twice with PBS and incubated with phalloidin (Alexa Fluor 568, 1:75 dilution in PBS) for $1 \mathrm{~h}$ at RT. Finally, samples were washed with PBS. The bottom and cross section of scaffolds were imaged using an inverted fluorescent microscope. Cross section images were analyzed using Image s software. Briefly, images were converted to 8-bits format and the local contrast was enhanced (blocksize 50, maximum slope 3, no mask). Next, the background was subtracted and the images were converted to binary (rendering regions with cells in white and the rest in black). Each image was divided into four regions corresponding to heights of $0-1 \mathrm{~mm}, 1-2 \mathrm{~mm}, 2-3 \mathrm{~mm}$, 3-4 $\mathrm{mm}$ starting from the bottom of the scaffolds and the total amount of white pixels in each region was quantified and normalized to the total number of pixels in the scaffold cross section. Values are reported as normalized cell coverage area in percentage. 


\subsection{Imaging of cell viability and macromolecules entrapment in $3 D$} scaffold

After 4 h seeding and 1 and 7 days of culture in scaffolds, dead cells were stained for 20 minutes prior to fixation using the LIVE/DEAD ${ }^{\mathrm{TM}}$ Fixable Dead Cell Stain Kit (Thermo Fisher Scientific) at a concentration of $0.5 \mu \mathrm{l}$ stain in $500 \mu \mathrm{l}$ Hank's Balanced Salt Solution per scaffold. Subsequently, samples were washed and fixed with 4 wt\% paraformaldehyde for $30 \mathrm{~min}$, followed by three washing steps with PBS. Cells were stained with phalloidin as stated in section 2.5. Live/dead images of scaffolds at day 1 and 7 were acquired using an inverted fluorescent microscopy. Confocal laser scanning microscopy of macroMs entrapment/dead cells at 4h and day 1 was performed with a Tandem confocal system (Leica TCS SP8 STED), equipped with a white light laser (WLL). Samples were excited with the dye specific wavelengths using the WLL or a photodiode 405 in the case of DAPI. Emission was detected with PMT detectors (DAPI) or HyD detectors (phalloidin, dextran-FITC, Ficoll-Pq-FITC, dead cells).

\subsection{Scanning electron microscopy (SEM) imaging of cells in scaffolds}

After $4 \mathrm{~h}$ seeding, 1 day of culture in BM and 28 days of culture in MM, scaffolds were washed with PBS and fixed with $4 \mathrm{wt} \%$ paraformaldehyde for $30 \mathrm{~min}$, followed by washing steps with PBS. Sample water content was removed with a graded ethanol series $(30,50,70,80,90,96,100 \mathrm{vol} \%)$, each $15 \mathrm{~min}$ at RT. Drying of samples was achieved by 15 min incubation in $100 \%$ ethanol- hexamethyldisilazane (HMDS) at a 1:1 ratio for $15 \mathrm{~min}$, followed by $15 \mathrm{~min}$ incubation in HMDS. HMDS was removed and scaffolds allowed overnight drying at RT. Samples were gold sputter coated and examined using SEM (Phillips XL-30), with the detector operating at $5 \mathrm{kV}$.

\subsection{Biochemical assays}

\subsubsection{ALP assay}

ALP activity was evaluated after 7 and 21 days of culture in MM (time points day 14 and 28, respectively). 3D scaffolds were collected at every time point and washed with PBS, cut in half, stored at $-80^{\circ} \mathrm{C}$ and freeze-thawed 3 times. Samples were incubated for $1 \mathrm{~h}$ at $\mathrm{RT}$ in a cell lysis buffer composed of $0.1 \mathrm{M}$ $\mathrm{KH}_{2} \mathrm{PO}_{4}, 0.1 \mathrm{M} \mathrm{K}_{2} \mathrm{HPO}_{4}$, and 0.1 vol\% Triton X-100, at pH 7.8. 40 $\mu \mathrm{l}$ of the chemiluminescent substrate for alkaline phosphatase CPD star (ready to use, Roche) was added to $10 \mu$ l of cell lysate. After $15 \mathrm{~min}$ incubation, luminescence (emission= $470 \mathrm{~nm}$ ) was measured using a spectrophotometer (CLARIOstar®, BMG Labtech). Remaining cell lysates were used for DNA quantification. Values are reported normalized to DNA content.

\subsubsection{DNA assay}

DNA assay was performed using CyQUANT Cell Proliferation Aasay Kit (Thermo Fisher Scientific) on cells cultured on 3D scaffolds after $4 \mathrm{~h}$ of seeding (time point day 0 ), after 7 days in BM (time point day 7), and after an extra 7 and 21 days of culture in BM or MM (time point day 14 and 28, respectively). In addition, DNA quantification was also performed on 2D samples. Samples (lysed samples from ALP activity assay or frozen samples after time point collection) were incubated overnight at $56^{\circ} \mathrm{C}$ in Proteinase $\mathrm{K}$ solution ( $1 \mathrm{mg} \mathrm{ml} \mathrm{m}^{-1}$ Proteinase $\mathrm{K}$ (Sigma-Aldrich) in Tris/EDTA) for matrix degradation and cell lysis. Subsequently, samples were freeze-thawed three times and incubated $1 \mathrm{~h}$ at RT with lysis buffer (cell lysis buffer from the kit diluted 20x in $\left.\mathrm{dH}_{2} \mathrm{O}\right)$ containing RNase A (1:500) to degrade cellular RNA. Lysed samples were incubated with the fluorescent dye provided by the kit (1:1) for $15 \mathrm{~min}$ and fluorescence was measured (emission/excitation $=520 / 480 \mathrm{~nm}$ ) with a spectrophotometer. DNA concentrations were calculated from a DNA standard curve.

\subsubsection{Alizarin red $S$ staining and quantification}

Calcium mineralization was qualitatively determined by alizarin red S staining after 7 and 21 days of culture in BM or MM (time point day 14 and 28, respectively). 3D scaffolds were washed with PBS and fixed with $4 \mathrm{wt} \%$ paraformaldehyde for $30 \mathrm{~min}$, followed by three washing steps in distilled water. Subsequently, scaffolds were cut in half and each section was stained with alizarin red $S$ solution (60 mM, pH 4.1-4.3) for $20 \mathrm{~min}$ at RT, and washed several times with distilled water until no more stain was leaching out. Images were taken using a stereomicroscope (Nikon SMZ25).

After imaging, a protocol adapted from Gregory et al. [43] was used to quantify calcium deposition. Briefly, stained samples were incubated in Eppendorf's for $1 \mathrm{~h}$ at RT with $30 \mathrm{vol} \%$ acetic acid while shaking, followed by $10 \mathrm{~min}$ incubation at $85^{\circ} \mathrm{C}$. Afterwards, scaffolds were removed and solutions were centrifuged at 20,000 rcf for $10 \mathrm{~min}$. An appropriate volume of $5 \mathrm{M}$ ammonium hydroxide was added to the supernatants to readjust the $\mathrm{pH}$ to 4.1-4.3. The absorbance was measured at $405 \mathrm{~nm}$ using a spectrophotometer. Concentration of alizarin red was calculated from an alizarin red standard curve and the values were normalized to DNA content.

\subsection{Gene expression}

Gene expression analysis was performed at day 14 (7 days in MM) and day 28 (21 days in MM). RNA was extracted from cells in scaffolds using a Trizol isolation method at the selected time points. Briefly, samples were transferred to Eppendorf tubes and Trizol was added. ECM was precipitated at the bottom of the tube through a centrifugation step at 12,000 rcf for 5 min. The supernatant was transferred to a new tube and chloroform was added to isolate the RNA, present in the aqueous phase after phase separation via centrifugation at 12,000 rcf for $5 \mathrm{~min}$. RNA was further purified using RNeasy mini kit column (Qiagen), according to the manufacturer's protocol. The purity and quantity of total RNA was evaluated using a spectrophotometer. Reverse transcription was performed using iScript ${ }^{\mathrm{TM}}$ (Bio-Rad) following suppliers' protocol. The obtained cDNA was used in combination with SYBRGreen master mix (Qiagen) and the selected primers (Table S1, Supplementary Information) to perform qPCR using CFX Connect ${ }^{\mathrm{TM}}$ Real-Time System (Bio-Rad) under the following conditions: cDNA was denaturated for $3 \mathrm{~min}$ at $95^{\circ} \mathrm{C}$, followed by 40 cycles consisting of $15 \mathrm{~s}$ at $95^{\circ} \mathrm{C}$ and $30 \mathrm{~s}$ at $65^{\circ} \mathrm{C}$. Additionally, a melting curve was generated for each reaction in order to test primer dimer formation and nonspecific amplification. Gene transcription was normalized to the transcription of the housekeeping human B2M gene. The $2^{-\Delta \Delta \mathrm{Ct}}$ method was used to calculate relative gene expression for each target gene. Normalization was done with respect to relative gene expression of cells in conventional seeding (CS) scaffolds at day 14.

\subsection{Statistical analysis}

Analysis of statistics was conducted with GraphPad Prism (version 8.0.1). A one-way or two-way ANOVA was performed with a post-hoc comparison to evaluate statistical significance. Data is shown as average of minimum 3 independent replicas with error bars indicating the standard deviation.

\section{Results}

\subsection{Optimization of the macromolecular seeding methods}

If cells in suspension are considered as rigid spheres, upon which frictional (viscosity related), buoyant (density related) and 

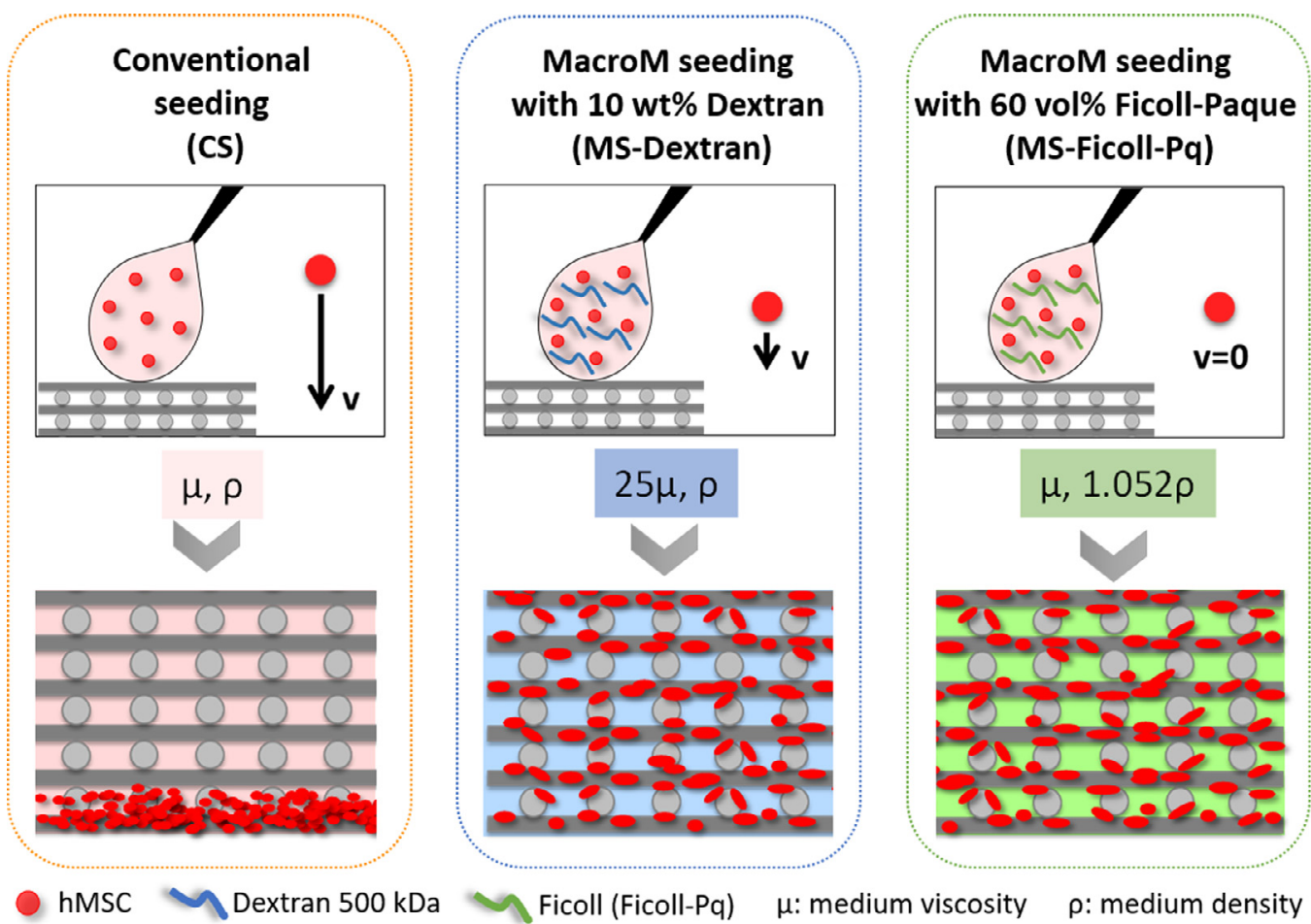

Ficoll (Ficoll-Pq) $\mu$ : medium viscosity $\rho$ : medium density

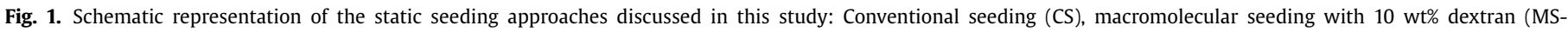

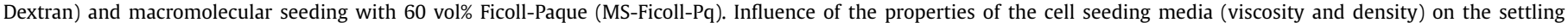
velocity of cells and, therefore, on cell attachment along scaffold height is depicted.

gravitational forces are exerted, their settling velocity in medium can be derived from the Stokes law [44]. When the sum of the frictional and buoyancy forces exerted on the cell, due to the surrounding medium, balance the gravitational force, the constant settling velocity (v) can be defined by:

$\mathrm{v}=\frac{2}{9} \frac{\left(\rho_{\text {cell }}-\rho_{\text {medium }}\right)}{\mu_{\text {medium }}} \mathrm{gR}^{2}$

where $\rho_{\text {cell }}$ refers to cell density, $\boldsymbol{\rho}_{\text {medium }}$ refers to density of the surrounding cell culture medium, $\boldsymbol{\mu}_{\text {medium }}$ refers to the viscosity of the surrounding cell culture medium, $g$ is the acceleration due to gravity, and $\mathrm{R}$ the cell hydrodynamic radius. According to this equation, to maintain cells in suspension the settling velocity can be decreased by increasing the media viscosity or reduced to zero by matching the density of the media and the cells. In this study, we investigated both approaches independently (Fig. 1). The media viscosity was changed with the addition of dextran. As shown in Fig. S1A (Supplementary Information), by the addition of dextran up to $10 \mathrm{wt} \%$, the viscosity of $\mathrm{CM}$ increases exponentially up to around 25 times. As our second approach, the density of the seeding medium was increased by the addition of Ficoll-Paque ${ }^{\mathrm{TM}}$ Plus (Ficoll-Pq) to match the cell density and therefore obtain a theoretical settling velocity equal to zero $(v=0)$. Ficoll-Pq is an aqueous solution that also contains sodium diatrizoate, a compound that allows to have a high density solution while maintaining its viscosity relatively low (Fig. S1B, Supplementary Information). Notably, the viscosity of this solution is only $\sim 3$ times higher than $\mathrm{CM}$ viscosity. A density gradient of Ficoll-Pq (Fig. S1D, Supplementary Information) allowed for the experimental determination of the density of the hMSCs, which is known to be lower than $1.073 \mathrm{~g} \mathrm{ml}^{-1}[45,46]$. Both separation by gradient centrifugation and by buoyancy forces determined that the density of the hMSCs population lied in between 1.034 and $1.052 \mathrm{~g} \mathrm{ml}^{-1}$ corresponding to $40 \mathrm{vol} \%$ and 60 vol\% Ficoll-Pq in CM (Fig. S2, Supplementary Information). In order to encompass the majority of the hMSCs population (i.e. to maintain most of the cells in suspension) 60 vol\% Ficoll-Pq solution (Ficoll-Pq -based CM) was chosen as the density-based media for seeding 3D scaffolds (MSFicoll-Pq), with a relatively ignorable influence on the viscosity of CM (only 1.65 fold increase) (Fig. S1B, Supplementary Information). On the other hand, the viscosity is considered the only effective parameter on the cell settling velocity in a $10 \mathrm{wt} \%$ Dextran solution (Dextran-based CM), which was chosen as the viscosity-based media for seeding the scaffolds (MS-Dextran).The density of $10 \mathrm{wt} \%$ dextran $\left(1.024 \mathrm{~g} \mathrm{ml}^{-1}\right)$ is significantly lower than 60 vol\% Ficoll-Pq density $\left(1.052 \mathrm{~g} \mathrm{ml}^{-1}\right)$ as well as 40 vol\% Ficoll-Pq density (1.034 $\mathrm{g} \mathrm{ml}^{-1}$ ), and therefore, lower than hMSCs density. Specifically, its density is comparable to that of a 20 vol\% Ficoll-Pq solution $\left(1.027 \mathrm{~g} \mathrm{ml}^{-1}\right)$ (Fig. S1C and E, Supplementary Information), where a minimum amount of cells were found during separation by Ficoll-Pq gradients (Fig. S2, Supplementary Information).

\subsection{Cell distribution using MS methods}

To assess the cell distribution across highly porous PEOT/PBT scaffolds seeded with each of the seeding methods, cells in their cross sections and bottoms were imaged and the cross section images were divided into four horizontal regions of $1 \mathrm{~mm}$ each, from 0 to $4 \mathrm{~mm}$ height. Moreover, cell settling velocity and displacement towards the bottom of scaffolds during the seeding time was calculated and used to support the cell localization results. As demonstrated in Fig. 2A and B, around $70 \%$ of the total cell number found in the scaffolds cross sections was concentrated in the lowest 1 $\mathrm{mm}$ region of the scaffold, as well as attached to the bottom, when seeded with the CS method. Using this method, cells sedimented at a theoretical velocity of $1.8 \mu \mathrm{m} \mathrm{s}^{-1}$ and displaced $2.6 \mathrm{~mm}$ towards the bottom of the scaffold ( $75 \%$ of the scaffold height) during the $4 \mathrm{~h}$ seeding (Fig. S1F, Supplementary Information). In contrast, theoretical cell settling velocity decreased $\sim 50$-fold for MS-Dextran when compared to the CS method, or remained zero when seeded 
A
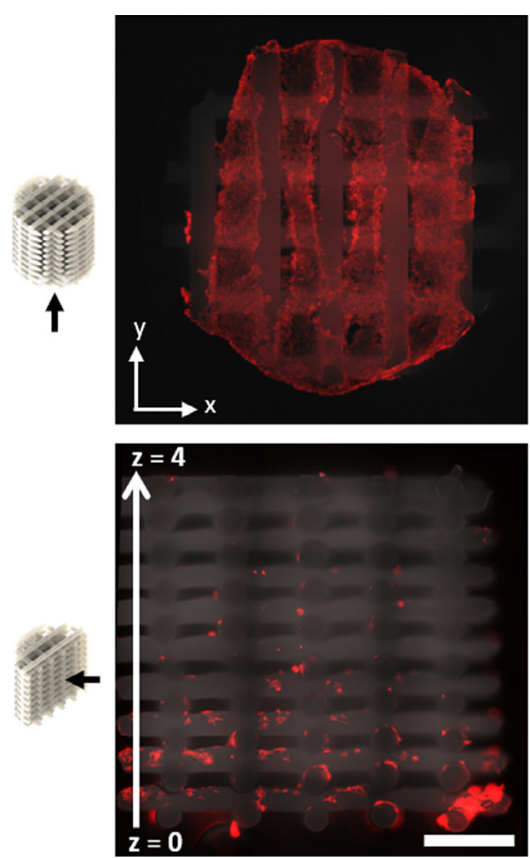

B

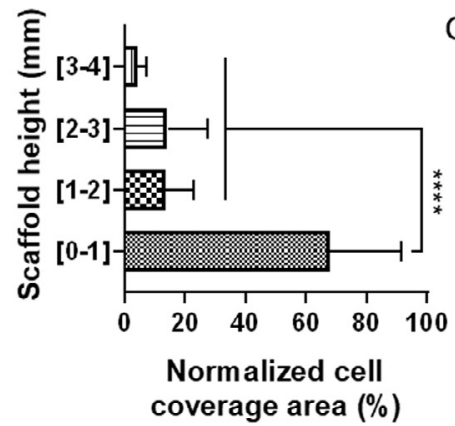

MS-Dextran
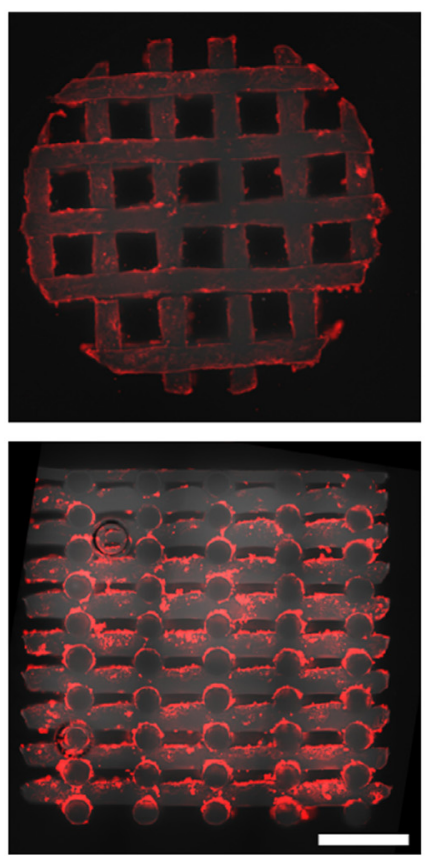

C

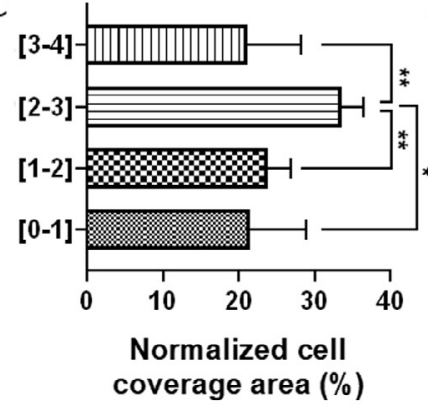

MS-Ficoll-Pq
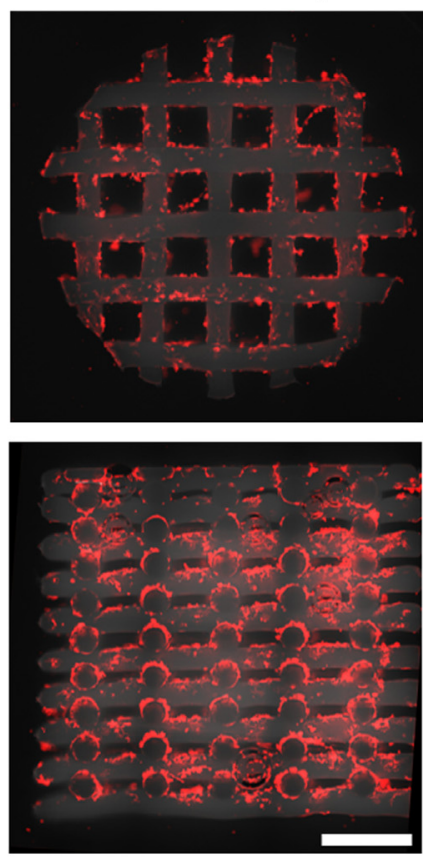

D

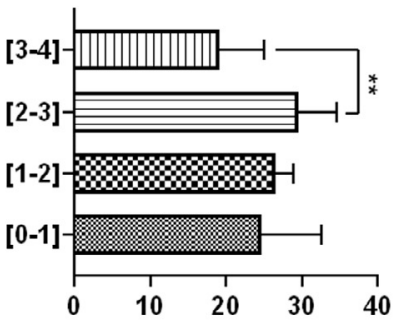

Normalized cell coverage area $(\%)$

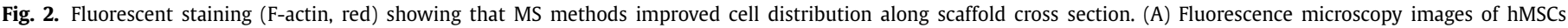

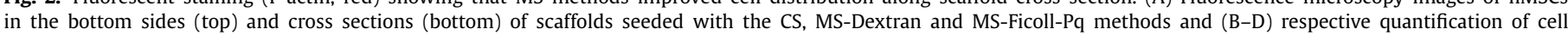

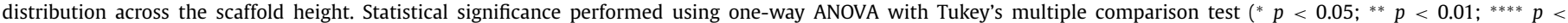
0.0001 ). Scale bars $1 \mathrm{~mm}$. (For interpretation of the references to color in this figure legend, the reader is referred to the web version of this article.)

with the MS-Ficoll-Pq method, resulting in a theoretical displacement of $\sim 55 \mu \mathrm{m}$ or $0 \mu \mathrm{m}$ towards the bottom of the scaffold during the $4 \mathrm{~h}$ seeding, respectively (Fig. S1F, Supplementary Information). This allowed the cells to remain in suspension and to attach to the filaments of the scaffolds in a more homogenous manner (Fig. 2A). Around 20 to $30 \%$ of the total cell number in the cross section was found in each of the $1 \mathrm{~mm}$ subdivisions of the scaffold (Fig. 2C and D), regardless of the use of the MS-Dextran or the MS-Ficoll-Pq method, suggesting that both approaches successfully improved cell distribution along scaffold's cross section. Furthermore, no cells were found at the bottom of scaffolds when seeded with the MS methods, contrary to what was observed in the case of CS scaffolds, which further demonstrates the enhanced cell attachment. Additionally, cells in suspension along the scaffolds depth that did not attach to the filaments were washed away after immersing the scaffolds in media (Video S1, Supplementary Information).

As observed in Fig. 3A, cells preferentially attached to the top curved surface of the scaffold filaments during the seeding and, due to cell clustering and a larger number of cells attached, cell projections were not clear in the MS-methods when compared to the spindle-like cells resulted from the CS method after $4 \mathrm{~h}$ seeding. Nevertheless, only after $24 \mathrm{~h}$ post-seeding cells in the MS scaffolds showed a clear elongated morphology, characteristic of migrating cells, and covered the whole surface of the filaments in contrast to the less crowded filaments on CS scaffolds (Fig. 3B).

\subsection{Macromolecules in scaffolds}

In order to evaluate the potential presence of macroMs in the scaffolds after seeding, scaffolds were seeded with solutions containing fluorescently labeled dextran or Ficoll. After $4 \mathrm{~h}$ seeding, macroMs were not found coating the scaffolds filaments. Besides, cells also sedimented in CS scaffolds, which were pre-incubated with dextran or Ficoll-Pq based CM (Fig. S3, Supplementary Information). Collectively, both results suggest that macroMs did not adhere to the scaffold surface to act as cell adhesive molecules nor contributed to better cell adhesion by mediating adsorption of serum proteins to the scaffolds filaments. Interestingly, while for both MS-Dextran and MS-Ficoll-Pq, macroMs co-localized with the cells cytoplasm after $4 \mathrm{~h}$ seeding (Fig. 4), their fluorescence signals were drastically reduced after $24 \mathrm{~h}$ and were found to co-localize only with dead cells (Fig. 4 and Fig. S4, Supplementary Information). Notably, cell death was visualized within the first minutes of hMSCs incubation with both macroMs based CM and CM (medium without macroMs) (Fig. S5, Supplementary Information). Nevertheless, high cell viability was observed across the 

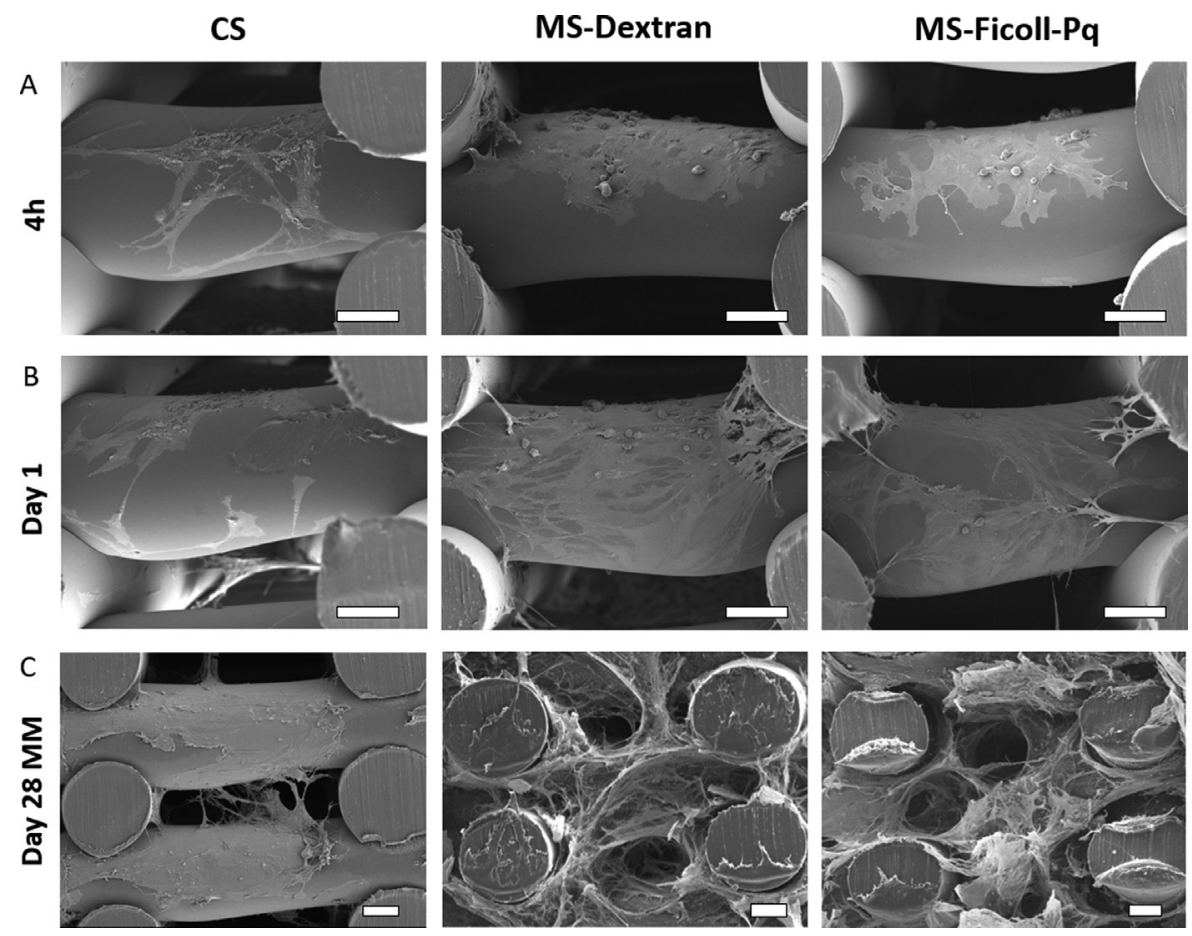

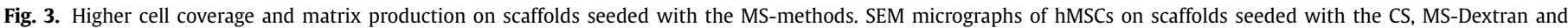

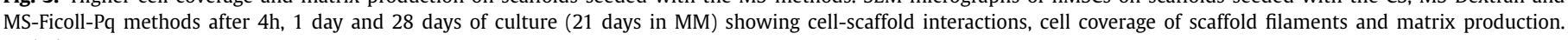
Scale bars $100 \mu \mathrm{m}$.
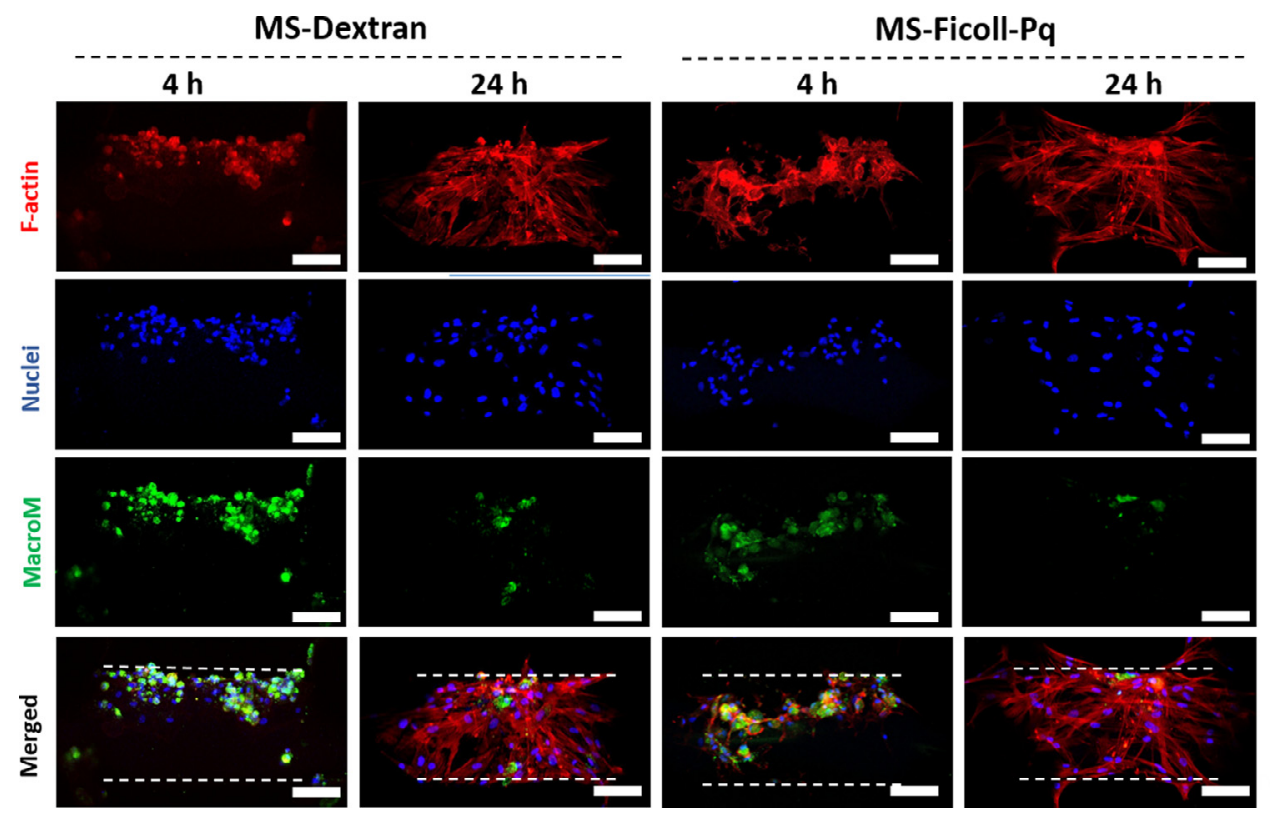

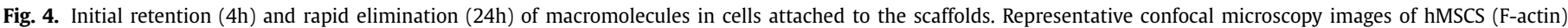

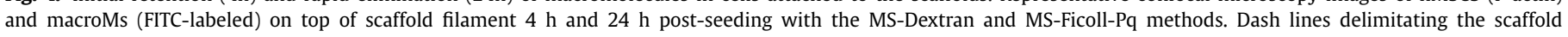
filament. Scale bars $100 \mu \mathrm{m}$.

MS-Dextran and MS-Ficoll-Pq scaffolds over 7 days culture, as demonstrated in the Fig. 5.

\subsection{Osteogenic differentiation on MS scaffolds}

To fully assess the functionality of our novel MS methods to seed AM 3D scaffolds for bone regeneration, hMSCs potency and their ability to undergo osteogenic differentiation after seeding was evaluated. Preliminary 2D experiments confirmed that proliferation and mineralization were not affected when cells were pre-incubated for $4 \mathrm{~h}$ in macroMs solutions and seeded in 2D (Fig. S6, Supplementary Information). These initial positive results allowed us to further study hMSCs response to macroMs seeding in 3D. Despite the significant effect of MS methods in cell distribution (Fig. 2), no statistical differences were found in the total number of cells attached to the scaffolds when compared to the CS method (Fig. 6A). Similarly, looking at cell proliferation (Fig. 6A), constant cell numbers were observed in scaffolds seeded with all the three methods over time, with the exception of day 28 in MM. At this timepoint, increased cell numbers were observed on MS 

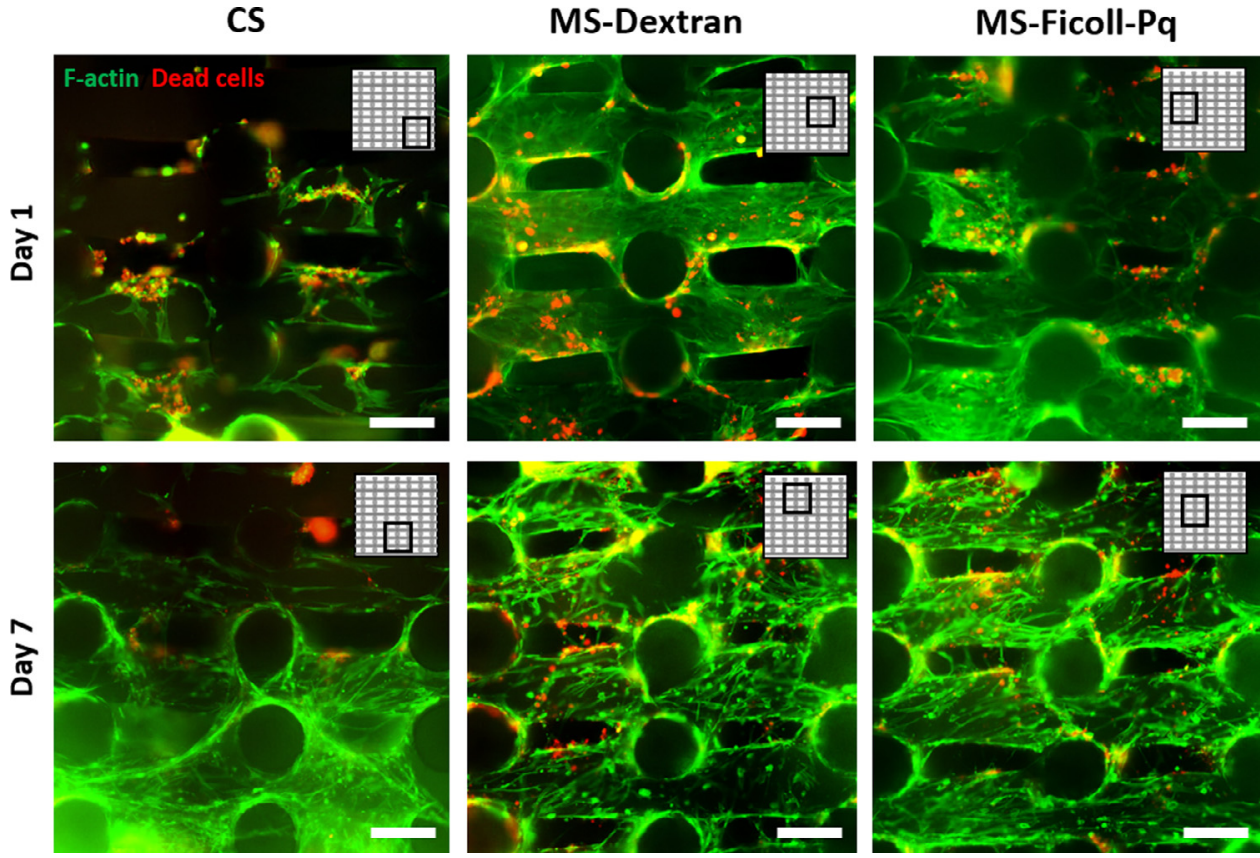

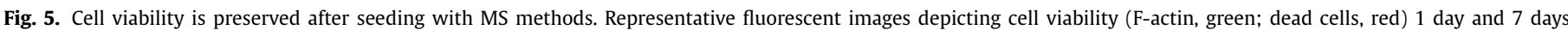

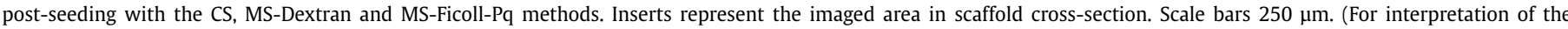
references to color in this figure legend, the reader is referred to the web version of this article.)

scaffolds, compared with earlier time points and with CS scaffolds at day 28. SEM images in Fig. $3 \mathrm{C}$ also demonstrated differences in ECM production at this timepoint among the seeding methods. In the case of MS scaffolds, cells were present both on the scaffold filaments and within poresvolume along with the formation of a dense ECM. On the contrary, ECM density was found to be much lower in CS scaffolds, which correlates to the low cell proliferation values over the whole culture period (Fig. 6A).

Alkaline phosphatase activity (ALP) was measured after 14 and 28 days of culture, corresponding to 7 and 21 days culture in MM (Fig. 6B). No significant difference was observed in ALP activity at day 14 regardless of the seeding method. However, ALP activity was significantly lower at day 28 when comparing cells in scaffolds seeded with CS and with MS methods. Interestingly, ALP activity increased from day 14 to day 28 in cells seeded with CS method. In contrast, ALP decreased from day 14 to day 28 in cells seeded with MS methods despite the macroM type.

To gain more insight into the potential of osteogenic differentiation of hMSCs in scaffolds seeded with our novel method, matrix mineralization was evaluated using alizarin red S staining to visualize calcium deposits after 7 and 21 days in MM (day 14 and day 28 , respectively). Scaffolds cultured in BM were used as controls to ensure the inert behavior of the macroMs in the mineralization process (Fig. S7A, Supplementary Information). Intriguingly, as it is shown in Fig. 6D, calcium deposition on the cross section of MS-scaffolds was observed from day 14 (7 days in MM), and by day 28 these were distributed over the whole scaffold visualized by the dense red color homogeneously covering the cross section and outer surface of the scaffolds (Fig. S7B, Supplementary Information). Quantification of the staining (Fig. 6C) confirmed that calcium depositions increased $\sim 10$ to 15 -fold within these two time points. Moreover, statistical differences among the amount of calcium deposited by cells seeded by the MS-dextran and the MS-Ficoll-Pq methods were evident when quantified. No ARS staining was observed in CS scaffolds at day 14, and only a small amount of calcium deposits was quantified after 28 days culture, which was comparable to the mineralization in MS scaffolds at day 14.
Ultimately, the expression of relevant osteogenic genes on cells seeded with the MS-methods was evaluated and compared to the CS-method. Notably, no significant differences were found in the expression of runt-related transcription factor (RUNX2), collagen I, osteocalcin and osteonectin among the different groups at day 14 (7 days in MM), suggesting that the seeding with macroMs did not alter the early stage of hMSCs differentiation (Fig. 7). Importantly, the gene encoding RUNX2 was upregulated on cells seeded with the MS-Dextran and MS-Ficoll-Pq at day 28 (21 days in MM) when compared to CS method (Fig. 7A). Similarly, collagen I expression was higher in MS-Ficoll-Pq samples at this time point (Fig. 7B). In addition, osteocalcin was more expressed in MS-Dextran with respect to CS (Fig. 7C). On the other hand, no significant differences were found in the osteonectin encoding gene expression among time points or seeding methods (Fig. 7D).

\section{Discussion}

When cells are seeded on a 2D substrate, gravity acts as one of the main parameters favoring cell attachment. On the contrary, gravity acts as a counterforce to cell attachment during static seeding of 3D scaffolds fabricated from synthetic polymers and with large and interconnected pores, where cell attachment is already dramatically hindered because of lack of adhesion motifs, fast flow velocity and large scaffold's pore size. Rather than modifying the scaffold material properties or architecture, in this study we tackled the cell sedimentation problem from a different perspective, the cell seeding media physical properties (viscosity and density). This is particularly a beneficial approach as it can be applied to all AM 3D scaffolds independent of their material chemistry or geometries. In this study we tuned the viscosity and density of the seeding media by using two natural biocompatible macromolecules, dextran and Ficoll. Dextran has previously shown to promote ECM deposition in vitro not only when used as macromolecular crowder mimicking the highly crowded/dense native ECM [47-49], but also when employed as media thickener to increase fluid shear forces in perfusion culture [50]. It has also been used to study erythrocyte aggregation and blood viscosity 
A

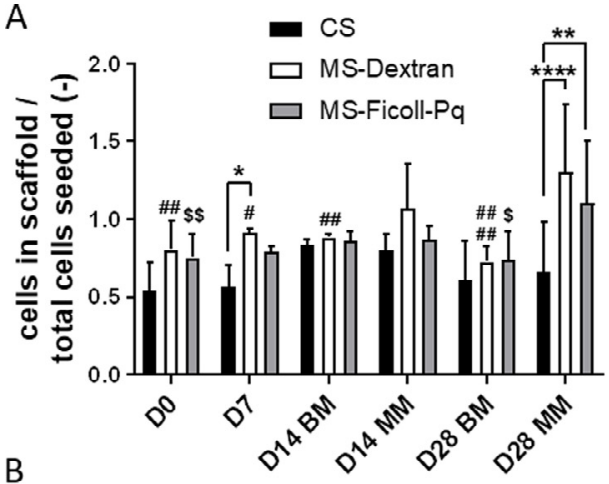

B

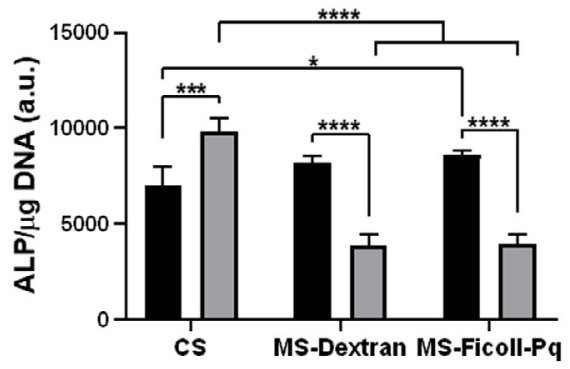

C

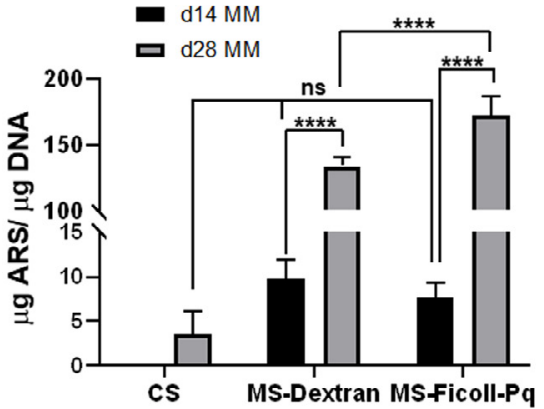

D
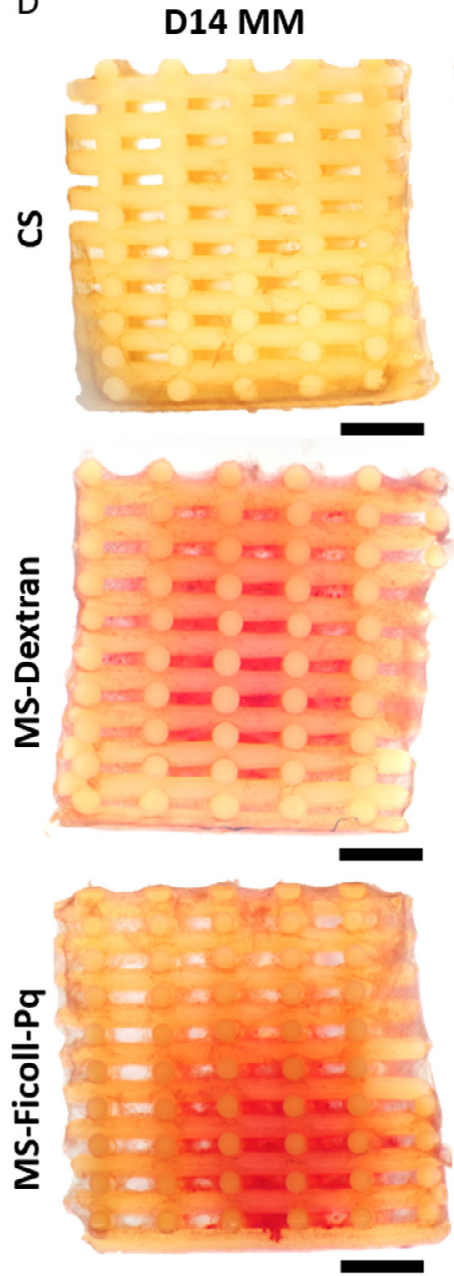

D28 MM
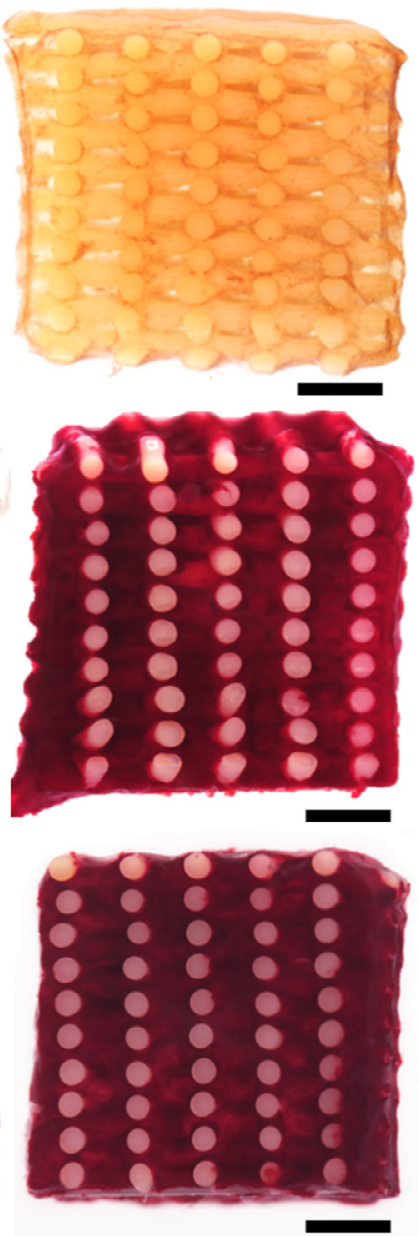

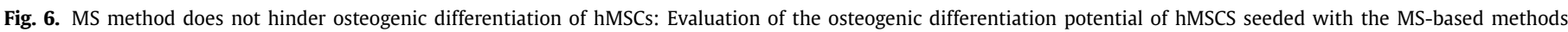

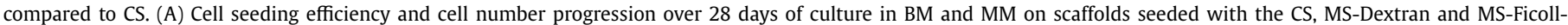

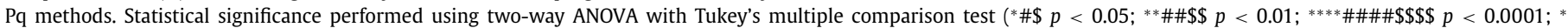

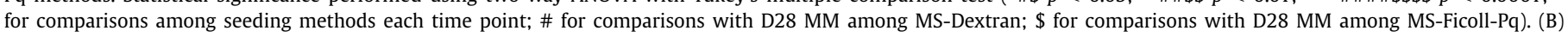

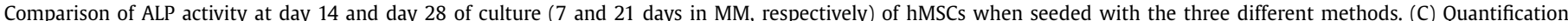

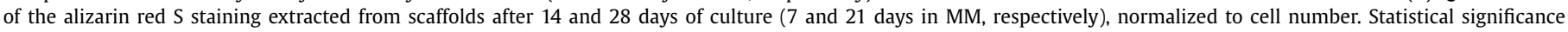

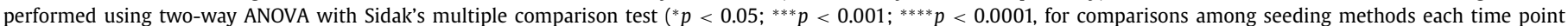

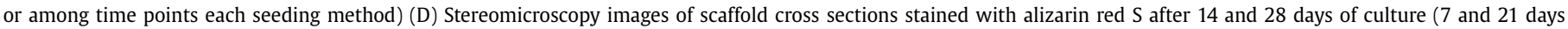
in MM, respectively). Scale bars $1 \mathrm{~mm}$ (For interpretation of the references to color in this figure legend, the reader is referred to the web version of this article.).

changes [51-53]. On the other hand, Ficoll has been used for the isolation of cells from blood samples by centrifugation $[49,50]$, as well as macromolecular crowding (MMC) agent [47-49,54]. Despite being widely used in the biomedical field, to the best of our knowledge, these macroMs were employed here for the first time as media supplements to enhance scaffolds static seeding. Moreover, we demonstrated that MS-Dextran and MS-Ficoll-Pq are two independent approaches, since viscosity and density are the effective parameters on cell settling velocity of the chosen dextran-based (10\% Dextran) and Ficoll-Pq -based (60 vol\% FicollPq) seeding solutions, respectively, and therefore the two methods can be studied and used separately. We showed that both increasing the seeding media viscosity or matching its density to that of hMSCs appropriately reduced cell settling velocity, allowing cells to float longer in the suspension, thereby giving them more time to attach, and hence promoting homogeneous cell attachment on the PEOT/PBT scaffold filaments. On the other hand, cells poorly attached to the scaffold cross section when using the CS method. PEOT/PBT was chosen as model synthetic material to produce 3D AM scaffolds. These polyether-ester multiblock copolymers are thermoplastic elastomers, whose surface energies, swellability, degradation and mechanical properties can be tuned for specific applications by controlling the PEOT/PBT ratio [2,55] and whose in vitro and in vivo applicability in the orthopedic field has been extensively studied $[56,57]$. Due to their easy processability, they have been previously used to produce 3D AM scaffolds [58]. However, they offer poor cell attachment upon conventional static seeding as shown here and in previous works [24,59].

Direct comparison of our cell distribution results with previously published seeding techniques on AM 3D scaffolds is very challenging, as most of these studies have not shown the full characterization of cell distribution and sedimentation, but rather addressed the seeding efficiency and its direct effect on the tissue regeneration process. In one exception, the amount of DAPI nuclear staining was quantified in each of the slices subdividing the cross section of scaffolds with vertical pore size gradients [32]. Despite the positive effect of gradients on cell attachment in each of the scaffold subdivisions, still large amounts of cells accumulated at the bottom of the scaffolds, leading to a non-uniform cell distribution over the scaffold cross section. Interestingly, the uniform 
A

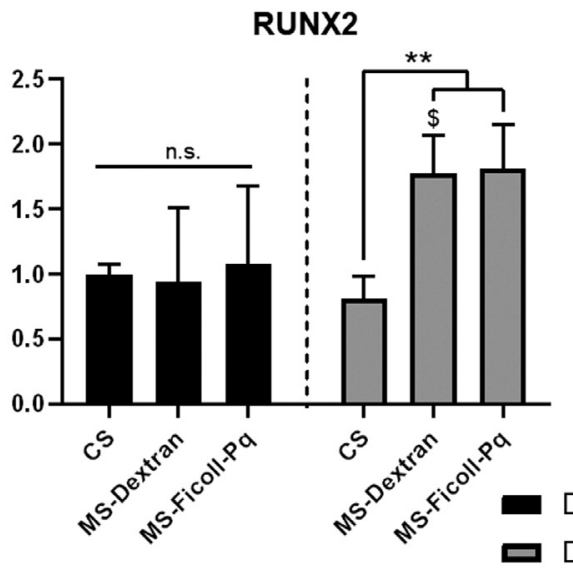

C

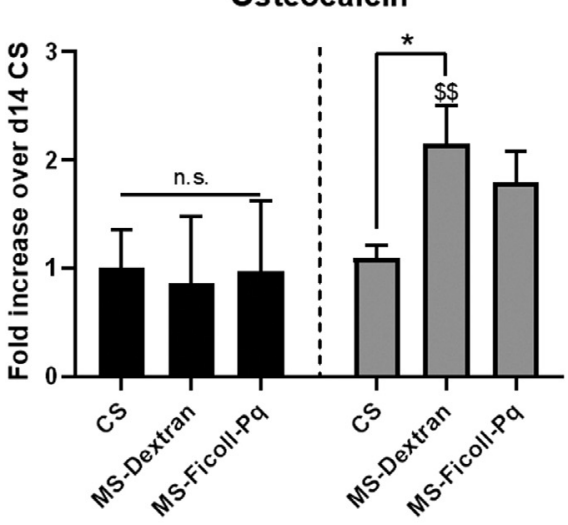

B

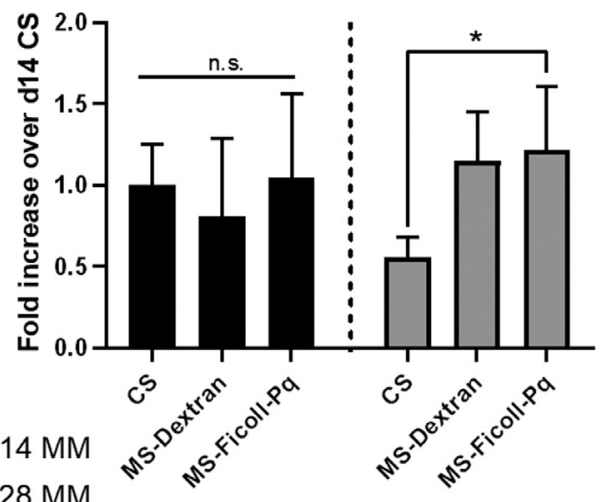

D

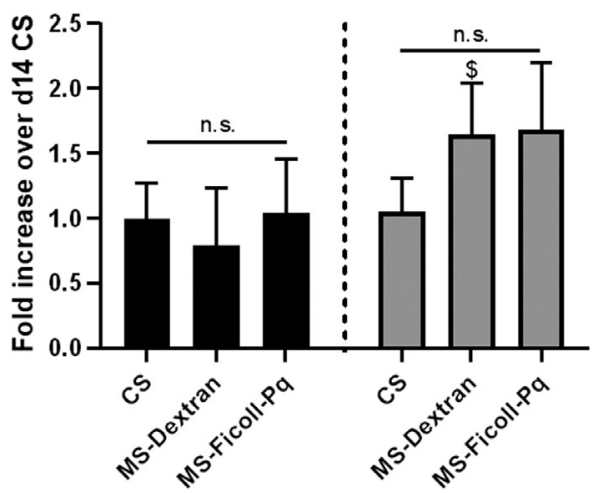

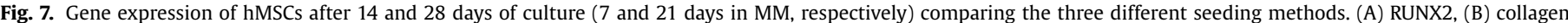

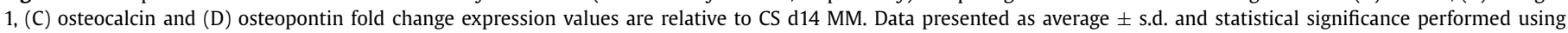

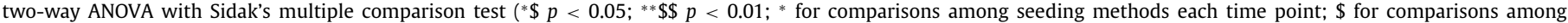
time points each seeding method).

cell distribution demonstrated by MS methods closely resembles a recently published report in which hMSCs were seeded in a polymeric scaffold by means of a cell-laden polyethylene glycol dithiothreitol hydrogel [40]. In this hybrid system, the cell carrier hydrogel was hydrolytically degraded after 7 days, time that cells used to populate the scaffold filaments attaining a good distribution. Importantly, when using our novel MS methods, cells attached directly to the filaments without the means of hydrogel carriers. Moreover, we proved that the macroMs did not act as a cell adhesive coating in the scaffolds, but viscosity or density of the media, depending on the macroM type, were the only factors leading to cell attachment. Previous reports demonstrating reduced protein adsorption and cell attachment in dextran coated surfaces support these results [60]: dextran and Ficoll should be functionalized to render them cell adhesive [61].

The fact that after the $4 \mathrm{~h}$ seeding the macroMs were found to colocalize with the cell cytoplasm and that the amount of macroMs was drastically reduced after $24 \mathrm{~h}$ culture in CM, suggests that the macroMs were internalized by cells during the seeding period, followed by their exocytosis towards the cell culture media after $24 \mathrm{~h}$. Fluorescently labeled dextran and Ficoll have been shown to enter different cell types, including hMSCs, by macropinocytosis [62,63] and micropinocytosis [64], respectively. Within the first $24 \mathrm{~h}$ after uptake, they have seen to accumulate in lysosomal compartments [64-66], were they degrade into glucose and fructose moieties. Moreover, since the cell culture media was renewed after $24 \mathrm{~h}$ culture and every 2 days from then on, the effect of the macroMs as crowders influencing ECM deposition can be ruled out. The absence of macroMs in the culture might be beneficial since no effect or even detrimental influence of macromolecular crowding has been shown on cartilaginous tissue formation in 3D [67]. This was hypothesized to be mainly due to the fact that in a 3D cell confluent system cells already reside in the crowded microenvironment consisting of their secreted matrices. Moreover additional crowding could lead to inefficient oxygen and waste management and the activation of degradation enzymes. However, there is lack of literature addressing the effect of MMC in 3D cell systems and thus, no definitive conclusions can be drawn.

Regarding cell death, it is hypothesized that it occurred before their incubation with macroMs as (i) it is known that internalized macroMs remain in the lysosomes with no effect on cellular function before their exocytosis to the extracellular space and (ii) cell death was also visualized within the first minutes of hMSCs incubation even with medium without macroMs. Hence, the presence of dead cells in the scaffold might be attributed to the low media-to-cell ratio during the $4 \mathrm{~h}$ seeding and to the handling of cells prior to seeding (centrifugation and resuspension in a small volume of medium), which are unavoidable issues of the seeding process. In this regard, the visualization of macroMs in the scaffold even after $24 \mathrm{~h}$ culture is attributed to the ability of macroM to penetrate the permeable membrane of dead cells during the seeding and the subsequent inability of these cells to process the macroMs [68].

Consistent with a previously published report, a cell monolayer was formed at the bottom of scaffolds seeded with CS method [24]. Notably, this was not observed in the case of MS scaffolds. It is plausible that the high cell density at the bottom of CS scaffolds enabled cell-to-cell and cell-to-scaffold contact after their fast 
sedimentation, while the low cell number localized at the bottom filaments region of MS-scaffolds, due to no cell sedimentation during MS methods and unattached cells washing after seeding, prevented the formation of a cell monolayer. Importantly, the sedimented cells which attached to the bottom of CS scaffolds, might have significantly contributed to the relatively higher seeding efficiency values than expected $(\sim 55 \%)$ for the high amount of cell settling observed, making it comparable to the MS methods seeding efficiency ( $80 \%$ and $\sim 75 \%$, for MS-Dextran and MS-Ficoll$\mathrm{Pq}$, respectively). In 2D, high cell seeding density (cells $\mathrm{cm}^{-2}$ ) has been demonstrated to direct and control early and late stage osteogenic markers and the temporal expression of MSCs genes towards osteogenesis [69]. However, cell density coupled to an optimum distribution of cells occupying the whole scaffold surface area are the parameters that will ultimately favor osteogenesis in a 3D environment. Therefore, cell number alone is not a primary factor and "efficiency" is defined by both cell density and cell distribution when culturing 3D scaffolds. In our case, due to the higher chance of cell attachment when seeded with the MS methods, cells were confluently occupying the scaffold filaments from the beginning of the culture, resulting in surface saturation and contact inhibition between adjacent cells [70], which explains the lack of proliferation on these scaffolds over 28 days in BM [71]. The increased matrix production in the MS scaffolds' pores volume when cultured in MM, might have offered the possibility to cells to grow not only on top of the scaffolds' filaments, but also on the ECM-filled scaffolds' pores. This increase in surface area available for cell proliferation between day 14 and day 28 was translated into an increase in cell number at late timepoints (day 28 in MM).

Overall, cell confluency over the MS scaffolds, coupled to the osteogenic factors included in MM, showed to have a positive effect on the osteogenic differentiation of the seeded hMSCs. This effect was initially demonstrated by the evaluation of ALP activity over the culture time, which is an early stage enzyme expressed in bone development and its upregulation precedes the upregulation of late osteogenic genes, such as osteocalcin, and matrix mineralization [72]. Decreasing ALP activity over time, which enables the development of the bone matrix by preparing the extracellular matrix for the deposition of mineral [72], has previously been observed in scaffolds with high cell seeding numbers, and therefore possibly better cell distribution [73]. Concordantly, a peak of ALP was seen at day 14 in MM, with values decreasing at day 28 in $\mathrm{MM}$ in cells seeded with MS methods despite the macroM type. On the contrary, ALP activity peaked after 28 days of culture in MM on scaffolds seeded with hMSCs via the CS method, as previously reported $[59,74]$. These dissimilarities are likely due to the aforementioned differences in cell number coupled to their distribution profile within the scaffolds. In agreement with with the ALP activity progression, extensive ECM was produced over time on MS scaffolds and ARS results showed enhanced and progressively increased mineralization on MS scaffolds over the culture in MM. However, no clear hypothesis has been drawn to explain the increased calcium deposition on MS-Ficoll-Pq scaffolds at day 28 when compared to MS-Dextran, since cell viability was preserved in both cases and cell numbers and ALP activity values at the time point are comparable among both scaffold types.

Analyzing the gene expression, we observed that the upregulation of relevant protein encoding genes involved in osteogenic differentiation at day 28 in MM in cells seeded with MS-methods, complements the abovementioned ALP activity and calcium deposition results. This further confirms that there is either a delay in the progression of osteogenesis in cells seeded with the CS method, or an acceleration in cells seeded with the MS methods, likely due to the differences in homogeneity in cell distribution. In particular, the gene encoding RUNX2, which is an essential transcription factor regulator of hMSCs differentiation into the os- teogenic lineage [75,76], was upregulated for cells on MS scaffolds. It is known to target specific osteogenic genes, such as collagen I, one of the major bone ECM components, or osteocalcin, one of the major bone non-collagenous proteins with the ability to bind bone hydroxyapatite [77]. Accordingly, collagen I and osteocalcin were upregulated in MS-Ficoll-Pq and MS-dextran scaffolds, respectively, when compared to CS scaffolds, suggesting matrix maturation. Although osteonectin was not differentially expressed in the MS scaffolds, this calcium binding non-collagenous protein has been found to be expressed in other non-mineralizing tissues, and therefore, lacks specificity [78]. While longer culture periods of CS scaffolds in MM might possibly lead to comparable results among different seeding methods [79], the possibility of speeding the osteogenic process of hMSCs by MS-methods is desired for both the in vitro and in vivo applications of the scaffolds.

\section{Conclusions}

Cell seeding on 3D AM scaffolds made of synthetic polymers with interconnected macroporosity still remains a challenge. The aim of this study was to develop a simple and reliable seeding technique to improve cell distribution upon static seeding valid for all 3D AM scaffolds regardless of their material properties and architecture. This was achieved by controlling the settling velocity of cells by altering the viscosity and density of the seeding media via the addition of two different macromolecules, dextran and Ficoll (Ficoll-Pq). Compared to scaffolds seeded with conventional static techniques, a homogeneous cell distribution was attained with direct cell attachment to the scaffold filaments. Importantly, macromolecules did not affect viability or osteogenic differentiation of hMSCs and their complete removal was demonstrated after the seeding period. Intriguingly, the improved cell distribution from the macroMs based seeding led to enhanced mineralization and bone matrix maturation compared to conventional seeding. These newly proposed seeding methods are simple, reproducible, and have the potential to improve the long-term functionality of in vitro and in vivo cell-seeded constructs for tissue engineering applications.

\section{Declaration of Competing Interest}

The authors declare that they have no known competing financial interests or personal relationships that could have appeared to influence the work reported in this paper.

\section{Acknowledgments}

We are grateful to H2020-NMP-PILOTS-2015 (GA n. 685825) for financial support.

\section{Supplementary materials}

Supplementary material associated with this article can be found, in the online version, at doi:10.1016/j.actbio.2019.11.020.

\section{References}

[1] E.S. Place, N.D. Evans, M.M. Stevens, Complexity in biomaterials for tissue engineering, Nat. Mater. 8 (2009) 457

[2] A.A. Deschamps, M.B. Claase, W.J. Sleijster, J.D. de Bruijn, D.W. Grijpma, J. Feijen, Design of segmented poly(ether ester) materials and structures for the tissue engineering of bone, J. Control. Release 78 (1) (2002) 175-186.

[3] S. Yang, K.-F. Leong, Z. Du, C.-K. Chua, The design of scaffolds for use in tissue engineering. Part I. traditional factors, Tissue Eng. 7 (6) (2001) 679-689.

[4] V. Karageorgiou, D. Kaplan, Porosity of 3D biomaterial scaffolds and osteogenesis, Biomaterials 26 (27) (2005) 5474-5491.

[5] C. Mota, D. Puppi, F. Chiellini, E. Chiellini, Additive manufacturing techniques for the production of tissue engineering constructs, J Tissue Eng Regen Med 9 (3) (2015) 174-190 
[6] M. Guvendiren, J. Molde, R.M.D. Soares, J. Kohn, Designing Biomaterials for 3D Printing, ACS Biomater. Sci. Eng. (2016).

[7] Y.S. Nam, J.J. Yoon, T.G. Park, A novel fabrication method of macroporous biodegradable polymer scaffolds using gas foaming salt as a porogen additive, J. Biomed. Mater. Res. 53 (1) (2000) 1-7.

[8] S.-S. Kim, M.S. Park, O. Jeon, C.Y. Choi, B.-S. Kim, Poly (lactide-co-glycolide)/hydroxyapatite composite scaffolds for bone tissue engineering, Biomaterials 27 (8) (2006) 1399-1409.

[9] C.M. Murphy, M.G. Haugh, F.J. O'Brien, The effect of mean pore size on cell attachment, proliferation and migration in collagen-glycosaminoglycan scaffolds for bone tissue engineering, Biomaterials 31 (3) (2010) 461-466.

[10] N. Sultana, M. Wang, PHBV/PLLA-based composite scaffolds fabricated using an emulsion freezing/freeze-drying technique for bone tissue engineering: surface modification and in vitro biological evaluation, Biofabrication 4 (1) (2012) 015003.

[11] G. Wei, P.X. Ma, Structure and properties of nano-hydroxyapatite/polymer composite scaffolds for bone tissue engineering, Biomaterials 25 (19) (2004) 4749-4757.

[12] R. Akbarzadeh, A.M. Yousefi, Effects of processing parameters in thermally induced phase separation technique on porous architecture of scaffolds for bone tissue engineering, J. Biomed. Mater. Res. B Appl. Biomater. 102 (6) (2014) 1304-1315.

[13] F.P. Luyten, F. Dell'Accio, C. De Bari, Skeletal tissue engineering: opportunities and challenges, Best Pract. Res. Clin. Rheumatol. 15 (5) (2001) 759-769.

[14] T. Hasegawa, M. Miwa, Y. Sakai, T. Niikura, S.Y. Lee, K. Oe, T. Iwakura, M. Kurosaka, T. Komori, Efficient cell-seeding into scaffolds improves bone formation, J. Dent. Res. 89 (8) (2010) 854-859.

[15] K. Burg, W. Holder Jr, C. Culberson, R. Beiler, K. Greene, A. Loebsack, W. Roland, P. Eiselt, D. Mooney, C. Halberstadt, Comparative study of seeding methods for three-dimensional polymeric scaffolds, J. Biomed. Mater. Res. 51 (4) (2000) 642-649.

[16] P. Thevenot, A. Nair, J. Dey, J. Yang, L. Tang, Method to analyze three-dimensional cell distribution and infiltration in degradable scaffolds, Tissue Eng. Part C: Methods 14 (4) (2008) 319-331.

[17] C. Weinand, J.W. Xu, G.M. Peretti, L.J. Bonassar, T.J. Gill, Conditions affecting cell seeding onto three-dimensional scaffolds for cellular-based biodegradable implants, J. Biomed. Mater. Res. Part B: Appl. Biomater. 91 (1) (2009) 80-87.

[18] J.F. Alvarez-Barreto, S.M. Linehan, R.L. Shambaugh, V.I. Sikavitsas, Flow perfusion improves seeding of tissue engineering scaffolds with different architectures, Ann. Biomed. Eng. 35 (3) (2007) 429-442.

[19] Z.-Z. Zhang, D. Jiang, S.-J. Wang, Y.-S. Qi, J.-Y. Zhang, J.-K. Yu, Potential of centrifugal seeding method in improving cells distribution and proliferation on demineralized cancellous bone scaffolds for tissue-engineered meniscus, ACS Appl. Mater. Interf. 7 (28) (2015) 15294-15302.

[20] E. Magrofuoco, M. Flaibani, M. Giomo, N. Elvassore, Cell culture distribution in a three-dimensional porous scaffold in perfusion bioreactor, Biochem. Eng. J. 146 (2019) 10-19.

[21] A.M. Leferink, Y.-C. Chng, C.A. van Blitterswijk, L. Moroni, Distribution and Viability of Fetal and Adult Human Bone Marrow Stromal Cells in a Biaxial Rotating Vessel Bioreactor after Seeding on Polymeric 3D Additive Manufactured Scaffolds, Front. Bioeng. Biotechnol. 3 (2015) 169-169.

[22] S. Impens, Y. Chen, S. Mullens, F. Luyten, J. Schrooten, Controlled cell-seeding methodologies: a first step toward clinically relevant bone tissue engineering strategies, Tissue Eng. Part C: Methods 16 (6) (2010) 1575-1583.

[23] Y. Chen, V. Bloemen, S. Impens, M. Moesen, F.P. Luyten, J. Schrooten, Characterization and optimization of cell seeding in scaffolds by factorial design: quality by design approach for skeletal tissue engineering, Tissue Eng. Part C: Methods 17 (12) (2011) 1211-1221.

[24] A.M. Leferink, W. Hendrikson, J. Rouwkema, M. Karperien, C. van Blitterswijk, L. Moroni, Increased cell seeding efficiency in bioplotted three-dimensional PEOT/PBT scaffolds, J. Tissue Eng. Regenerat. Med. 10 (8) (2016) 679-689.

[25] E.D. Yildirim, D. Pappas, S. Güçeri, W. Sun, Enhanced cellular functions on polycaprolactone tissue scaffolds by $\mathrm{O} 2$ plasma surface modification, Plasma Processes Polym. 8 (3) (2011) 256-267.

[26] M. Domingos, F. Intranuovo, A. Gloria, R. Gristina, L. Ambrosio, P.J. Bártolo, P. Favia, Improved osteoblast cell affinity on plasma-modified 3-D extruded PCL scaffolds, Acta Biomater. 9 (4) (2013) 5997-6005.

[27] J. HoJun, L. Hyeongjin, K. GeunHyung, A Surface-Modified Poly( $\varepsilon$-caprolactone) Scaffold Comprising Variable Nanosized Surface-Roughness Using a Plasma Treatment, Tissue Eng. Part C Methods 20 (12) (2014) 951-963.

[28] P. Cools, C. Mota, I. Lorenzo-Moldero, R. Ghobeira, N. De Geyter, L. Moroni, R. Morent, Acrylic Acid Plasma Coated 3D Scaffolds for Cartilage tissue engineering applications, Sci. Rep. 8 (1) (2018) 3830.

[29] S. Jo, S.M. Kang, S.A. Park, W.D. Kim, J. Kwak, H. Lee, Enhanced Adhesion of Preosteoblasts inside 3D PCL Scaffolds by Polydopamine Coating and Mineralization, Macromol. Biosci. 13 (10) (2013) 1389-1395.

[30] S.J. Lee, D. Lee, T.R. Yoon, H.K. Kim, H.H. Jo, J.S. Park, J.H. Lee, W.D. Kim, I.K. Kwon, S.A. Park, Surface modification of 3D-printed porous scaffolds via mussel-inspired polydopamine and effective immobilization of rhBMP-2 to promote osteogenic differentiation for bone tissue engineering, Acta Biomater. 40 (2016) 182-191.

[31] C.-T. Kao, C.-C. Lin, Y.-W. Chen, C.-H. Yeh, H.-Y. Fang, M.-Y. Shie, Poly(dopamine) coating of 3D printed poly(lactic acid) scaffolds for bone tissue engineering, Mater. Sci. Eng. C 56 (2015) 165-173.

[32] J.M. Sobral, S.G. Caridade, R.A. Sousa, J.F. Mano, R.L. Reis, Three-dimensional plotted scaffolds with controlled pore size gradients: Effect of scaffold geom- etry on mechanical performance and cell seeding efficiency, Acta Biomater. 7 (3) (2011) 1009-1018.

[33] B. Ostrowska, A. Di Luca, L. Moroni, W. Swieszkowski, Influence of internal pore architecture on biological and mechanical properties of three-dimensional fiber deposited scaffolds for bone regeneration, J. Biomed. Mater. Res. Part A (2016).

[34] D.W. Hutmacher, Scaffolds in tissue engineering bone and cartilage, Biomaterials 21 (24) (2000) 2529-2543.

[35] S. Van Bael, Y.C. Chai, S. Truscello, M. Moesen, G. Kerckhofs, H. Van Oosterwyck, J.P. Kruth, J. Schrooten, The effect of pore geometry on the in vitro biological behavior of human periosteum-derived cells seeded on selective laser-melted Ti6Al4V bone scaffolds, Acta Biomater. 8 (7) (2012) 2824-2834.

[36] A.A. Zadpoor, Bone tissue regeneration: the role of scaffold geometry, Biomater. Sci. 3 (2) (2015) 231-245.

[37] L. Dong, S.-J. Wang, X.-R. Zhao, Y.-F. Zhu, J.-K. Yu, 3D- Printed Poly( $\varepsilon$-caprolactone) Scaffold Integrated with Cell-laden Chitosan Hydrogels for Bone Tissue Engineering, Sci. Rep. 7 (1) (2017) 13412.

[38] A. Papadimitropoulos, S.A. Riboldi, B. Tonnarelli, E. Piccinini, M.A. Woodruff, D.W. Hutmacher, I. Martin, A collagen network phase improves cell seeding of open-pore structure scaffolds under perfusion, Journal of Tissue Engineering and Regenerative Medicine 7 (3) (2013) 183-191.

[39] M. Markovic, J. Van Hoorick, K. Hölzl, M. Tromayer, P. Gruber, S. Nürnberger, P. Dubruel, S. Van Vlierberghe, R. Liska, A. Ovsianikov, Hybrid tissue engineering scaffolds by combination of three-dimensional printing and cell photoencapsulation, Journal of Nanotechnology in Engineering and Medicine 6 (2) (2015) 021001

[40] M. Whitely, S. Cereceres, P. Dhavalikar, K. Salhadar, T. Wilems, B. Smith, A. Mikos, E. Cosgriff-Hernandez, Improved in situ seeding of 3D printed scaffolds using cell-releasing hydrogels, Biomaterials 185 (2018) 194-204.

[41] W.J. Kim, H.-S. Yun, G.H. Kim, An innovative cell-laden $\alpha$-TCP/collagen scaffold fabricated using a two-step printing process for potential application in regenerating hard tissues, Sci. Rep. 7 (1) (2017) 3181-3181.

[42] A.J. Engler, S. Sen, H.L. Sweeney, D.E. Discher, Matrix elasticity directs stem cell lineage specification, Cell 126 (4) (2006) 677-689.

[43] C.A. Gregory, W.G. Gunn, A. Peister, D.J. Prockop, An Alizarin red-based assay of mineralization by adherent cells in culture: comparison with cetylpyridinium chloride extraction, Anal. Biochem. 329 (1) (2004) 77-84.

[44] Lamb, Hydrodynamics, 6th ed., Cambridge University Press, Cambridge, 1994.

[45] Y. Chang, P.H. Hsieh, C.C. Chao, The efficiency of Percoll and Ficoll density gradient media in the isolation of marrow derived human mesenchymal stem cells with osteogenic potential, Chang Gung Med. J. 32 (3) (2009) 264 275.

[46] C.L. Insausti, M.B. Blanquer, L.M. Olmo, M.C. López-Martínez, X.F. Ruiz, F.J.R. Lozano, V.C. Perianes, C. Funes, F.J. Nicolás, M.J. Majado, J.M.M. Jiménez, Isolation and Characterization of Mesenchymal Stem Cells from the Fat Layer on the Density Gradient Separated Bone Marrow, Stem Cells Dev. 21 (2) (2012) 260-272.

[47] C. Chen, F. Loe, A. Blocki, Y. Peng, M. Raghunath, Applying macromolecular crowding to enhance extracellular matrix deposition and its remodeling in vitro for tissue engineering and cell-based therapies, Adv. Drug. Deliv. Rev. 63 (4) (2011) 277-290.

[48] A. Satyam, P. Kumar, X. Fan, A. Gorelov, Y. Rochev, L. Joshi, H. Peinado, D. Lyden, B. Thomas, B. Rodriguez, A. Pandit, D. Zeugolis, Macromolecular crowding meets tissue engineering by self-assembly: A paradigm shift in regenerative medicine, Adv. Mater. 26 (19) (2014) 3024-3034.

[49] R.R. Lareu, K.H. Subramhanya, Y. Peng, P. Benny, C. Chen, Z. Wang, R. Rajagopalan, M. Raghunath, Collagen matrix deposition is dramatically enhanced in vitro when crowded with charged macromolecules: the biological relevance of the excluded volume effect, FEBS Lett. 581 (14) (2007) 2709-2714.

[50] V.I. Sikavitsas, G.N. Bancroft, H.L. Holtorf, J.A. Jansen, A.G. Mikos, Mineralized matrix deposition by marrow stromal osteoblasts in 3D perfusion culture increases with increasing fluid shear forces, Proc. Natl. Acad. Sci. 100 (25) (2003) 14683-14688.

[51] W.I. Rosenblum, Effects of Dextran-40 on Blood Viscosity in Experimental Macroglobulinaemia, Nature 218 (5141) (1968) 591-593.

[52] A. Pribush, D. Zilberman-Kravits, N. Meyerstein, The mechanism of the dextran-induced red blood cell aggregation, Eur. Biophys. J. 36 (2) (2007) 85-94.

[53] B. Neu, R. Wenby, H.J. Meiselman, Effects of dextran molecular weight on red blood cell aggregation, Biophys. J. 95 (6) (2008) 3059-3065.

[54] P. Kumar, A. Satyam, X. Fan, E. Collin, Y. Rochev, B.J. Rodriguez, A. Gorelov, S. Dillon, L. Joshi, M. Raghunath, Macromolecularly crowded in vitro microenvironments accelerate the production of extracellular matrix-rich supramolecular assemblies, Sci. Rep. 5 (2015) 8729.

[55] A.A. Deschamps, D.W. Grijpma, J. Feijen, Poly(ethylene oxide)/poly(butylene terephthalate) segmented block copolymers: the effect of copolymer composition on physical properties and degradation behavior, Polymer 42 (23) (2001) 9335-9345.

[56] C. Van Blitterswijk, H. Leenders, D. Baaker, The effect of PEO ratio on degradation, calcification and bone bonding of PEO/PBT copolymer (PolyActive), Cells Mater. 3 (1) (1993) 2.

[57] E.J.P. Jansen, J. Pieper, M.J.J. Gijbels, N.A. Guldemond, J. Riesle, L.W. Van Rhijn, S.K. Bulstra, R. Kuijer, PEOT/PBT based scaffolds with low mechanical properties improve cartilage repair tissue formation in osteochondral defects, J. Biomed. Mater. Res. Part A 89A (2) (2009) 444-452. 
[58] L. Moroni, J. De Wijn, C. Van Blitterswijk, 3D fiber-deposited scaffolds for tissue engineering: influence of pores geometry and architecture on dynamic mechanical properties, Biomaterials 27 (7) (2006) 974-985.

[59] A. Di Luca, B. Ostrowska, I. Lorenzo-Moldero, A. Lepedda, W. Swieszkowski, C. Van Blitterswijk, L. Moroni, Gradients in pore size enhance the osteogenic differentiation of human mesenchymal stromal cells in three-dimensional scaffolds, Sci. Rep. 6 (2016) 22898.

[60] S.P. Massia, J. Stark, D.S. Letbetter, Surface-immobilized dextran limits cell adhesion and spreading, Biomaterials 21 (22) (2000) 2253-2261.

[61] G. Sun, J.J. Mao, Engineering dextran-based scaffolds for drug delivery and tissue repair, Nanomedicine 7 (11) (2012) 1771-1784.

[62] B.K.K. Teo, S.-H. Goh, T.S. Kustandi, W.W. Loh, H.Y. Low, E.K.F. Yim, The effect of micro and nanotopography on endocytosis in drug and gene delivery systems, Biomaterials 32 (36) (2011) 9866-9875.

[63] L.I. Sánchez-Abarca, I. Álvarez-Laderas, M. Díez Campelo, T. Caballero-Velázquez, C. Herrero, S. Muntión, C. Calderón, E. García-Guerrero, F. Sánchez-Guijo, C. del Cañizo, J. San Miguel, J.A. Pérez-Simón, Uptake and delivery of antigens by mesenchymal stromal cells, Cytotherapy 15 (6) (2013) 673-678.

[64] R. Rashid, S. Beyer, A. Blocki, C. Le Visage, D. Trau, T. Wohland, M. Raghunath, Mitochondrial Routing of Glucose and Sucrose Polymers after Pinocytotic Uptake: Avenues for Drug Delivery, Biomacromolecules 15 (6) (2014) 2119-2127.

[65] A. Dragonetti, M. Baldassarre, R. Castino, M. Demoz, A. Luini, R. Buccione, C. Isidoro, The lysosomal protease cathepsin D is efficiently sorted to and secreted from regulated secretory compartments in the rat basophilic/mast cell line RBL, J. Cell Sci. 113 (18) (2000) 3289-3298.

[66] R. Cohen, K. Corwith, D. Holowka, B. Baird, Spatiotemporal resolution of mast cell granule exocytosis reveals correlation with Ca2+ wave initiation, J. Cell Sci. 125 (12) (2012) 2986-2994.

[67] B. Chen, B. Wang, W.J. Zhang, G. Zhou, Y. Cao, W. Liu, Macromolecular crowding effect on cartilaginous matrix production: a comparison of two-dimensional and three-dimensional models, Tissue Eng. Part C: Methods 19 (8) (2013) 586-595.

[68] M. Moumaris, B. Rajoelya, N. Abuafa, Fluorescein isothiocyanate-dextran can track apoptosis and necrosis induced by heat shock of peripheral blood mononuclear cells and HeLa cells, Open Biol. Sci. J. 1 (1) (2015).

[69] K. Kim, D. Dean, A.G. Mikos, J.P. Fisher, Effect of Initial Cell Seeding Density on Early Osteogenic Signal Expression of Rat Bone Marrow Stromal Cells Cultured on Cross-Linked Poly(propylene fumarate) Disks, Biomacromolecules 10 (7) (2009) 1810-1817.
[70] H. Eagle, E.M. Levine, Growth regulatory effects of cellular interaction, Nature 213 (5081) (1967) 1102-1106.

[71] A. Lode, A. Bernhardt, M. Gelinsky, Cultivation of human bone marrow stromal cells on three-dimensional scaffolds of mineralized collagen: influence of seeding density on colonization, proliferation and osteogenic differentiation, J. Tissue Eng. Regenerat. Med. 2 (7) (2008) 400-407.

[72] T.A. Owen, M. Aronow, V. Shalhoub, L.M. Barone, L. Wilming, M.S. Tassinari, M.B. Kennedy, S. Pockwinse, J.B. Lian, G.S. Stein, Progressive development of the rat osteoblast phenotype in vitro: reciprocal relationships in expression of genes associated with osteoblast proliferation and differentiation during formation of the bone extracellular matrix, J. Cell. Physiol. 143 (3) (1990) 420-430.

[73] Y.F. Zhou, V. Sae-Lim, A.M. Chou, D.W. Hutmacher, T.M. Lim, Does seeding density affect in vitro mineral nodules formation in novel composite scaffolds? J. Biomed. Mater. Res. Part A 78A (1) (2006) 183-193.

[74] A. Di Luca, A. Longoni, G. Criscenti, C. Mota, C. van Blitterswijk, L. Moroni, Toward mimicking the bone structure: design of novel hierarchical scaffolds with a tailored radial porosity gradient, Biofabrication 8 (4) (2016) 045007.

[75] T. Komori, H. Yagi, S. Nomura, A. Yamaguchi, K. Sasaki, K. Deguchi, Y. Shimizu, R.T. Bronson, Y.H. Gao, M. Inada, M. Sato, R. Okamoto, Y. Kitamura, S. Yoshiki, T. Kishimoto, Targeted disruption of Cbfa1 results in a complete lack of bone formation owing to maturational arrest of osteoblasts, Cell 89 (5) (1997) $755-764$.

[76] Y. Li, C. Ge, J.P. Long, D.L. Begun, J.A. Rodriguez, S.A. Goldstein, R.T. Franceschi, Biomechanical stimulation of osteoblast gene expression requires phosphorylation of the RUNX2 transcription factor, J. Bone Miner. Res. 27 (6) (2012) 1263-1274.

[77] K.K. Ivaska, T.A. Hentunen, J. Vaaraniemi, H. Ylipahkala, K. Pettersson, H.K. Vaananen, Release of intact and fragmented osteocalcin molecules from bone matrix during bone resorption in vitro, J. Biol. Chem. 279 (18) (2004) $18361-18369$.

[78] E.M. Rosset, A.D. Bradshaw, SPARC/osteonectin in mineralized tissue, Matrix Biol. J. Int. Soc. Matrix Biol. 52-54 (2016) 78-87.

[79] C.E. Holy, M.S. Shoichet, J.E. Davies, Engineering three-dimensional bone tissue in vitro using biodegradable scaffolds: Investigating initial cell-seeding density and culture period, J. Biomed. Mater. Res. 51 (3) (2000) 376-382. 